\title{
Connectedness as a Core Conservation Concern: An Interdisciplinary Review of Theory and a Call for Practice
}

\author{
Matthew J. Zylstra $\cdot$ Andrew T. Knight • \\ Karen J. Esler • Lesley L. L. Le Grange
}

Received: 30 January 2013/Revised: 28 July 2014/ Accepted: 5 September 2014/Published online: 23 September 2014

(C) Springer International Publishing AG 2014

\begin{abstract}
Calls for society to 'reconnect with nature' are commonplace in the scientific literature and popular environmental discourse. However, the expression is often used haphazardly without the clarity of the process involved, the practical outcomes desired, and/or the relevance to conservation. This interdisciplinary review finds that the Western disconnect from nature is central to the convergent social-ecological crises and is primarily a problem in consciousness. Connectedness with nature $(\mathrm{CWN})$ is therefore defined as a stable state of consciousness comprising symbiotic cognitive, affective, and experiential traits that reflect, through consistent attitudes and behaviors, a sustained awareness of the interrelatedness between one's self and the rest of nature. CWN sits on a continuum comprising information about nature and experience in nature but is differentiated as a more holistic process for realizing transformative outcomes that serve oneself and
\end{abstract}

Endorsed by Karen J. Esler.

M. J. Zylstra $(\bowtie) \cdot$ K. J. Esler

Department of Conservation Ecology \& Entomology,

Stellenbosch University, Stellenbosch, South Africa

e-mail: matt@earthcollective.net

K. J. Esler

e-mail: kje@sun.ac.za

A. T. Knight

Department of Life Sciences, Imperial College London, London, UK

K. J. Esler

Centre for Invasion Biology, Stellenbosch University,

Stellenbosch, South Africa

L. L. L. Le Grange

Department of Curriculum Studies, Faculty of Education,

Stellenbosch University, Stellenbosch, South Africa their community. Various instruments are available to measure the CWN construct, although their cross-cultural transferability is unclear. Multiple benefits of CWN linked to physical and psychological well-being have been identified and CWN is distinct in that it supports happiness and more purposeful, fulfilling, and meaningful lives. CWN has been found as a reliable predictor and motivation for environmentally responsible behavior (ERB). CWN may benefit conservation discourse by providing: a more compelling language; hope and buffering frustration in the face of environmental crises; a more enduring motivation for ERB; and an accepted avenue for tackling 'fuzzy' concepts often avoided in conservation. Bolstered by interdisciplinary collaborations and action-oriented education, CWN presents itself as a radical but necessary prerequisite for realizing desired conservation and environmental behavior outcomes.

Keywords Connection with nature $\cdot$ Environmental behavior · Human-nature relationships - Nature experience $\cdot$ Environmental concern $\cdot$ Conservation and sustainability education

\section{Motivation}

- The human disconnect from nature is at the heart of the perceived environmental crisis

- This separation from nature is driven by physical and psychological factors, with the latter signifying a problem of consciousness

- CWN is a stable state of consciousness comprising symbiotic cognitive, affective, and experiential dimensions that reflect a realization of the interrelatedness between one's self and the rest of nature 
- CWN is positively linked with ERB and multiple variables supporting human well-being, including happiness.

- Existing theoretical knowledge of CWN needs to be matched by greater transdisciplinary collaboration in conservation and education to support the practice and empirical-based evaluation of CWN implementation

- CWN is foundational to effective conservation practice and ERB and should therefore be prioritized in related education strategies

\section{The Call to Reconnect with Nature}

"Reconnect with nature" has become the mantra for addressing humanity's severance from the natural world. This perceived separation is widely viewed as the primary driver behind the global environmental crisis [1-7]. In identifying future challenges for conservation biology, Balmford and Cowling [8, p. 694] see

...a great need for interdisciplinary efforts to tackle perhaps the most pervasive underlying threat of all by reconnecting people and nature...even if all the other building blocks of effective conservation are in place, we will not succeed unless the general public cares, and they are unlikely to care enough if they no longer experience nature directly.

This call echoes the views of ecologists, environmental educators, and nature writers who have long stressed the importance of individuals' connectedness with nature (CWN) in fostering an ethic that motivates people to become more engaged citizens who practice environmentally responsible behavior (ERB) to support resilient socialecological systems [3, 4, 9-15]. This call also finds support in many natural history or bio-philosophical treatises $[2,7$, 16].

However, despite the case for CWN being replete in the literature from, for example, ecophilosophy, public health, environmental education, nature-based tourism, outdoor adventure, and multiple psychology disciplines, global society has made little progress in achieving aspirations toward CWN or behaviors which sustain biodiversity and healthy ecosystems [8, 12, 17]. There is also an apparent lack of appreciation in government, business, and the general populace about the significance of $\mathrm{CWN}$ and its relevance to societal problems [2, 3]. Notwithstanding the mounting empirical evidence and calls for society to "reconnect with nature," a critical mass of decision-makers and opinion leaders in governance, science, and education circles have failed to grasp the significance of CWN in theory and practice in terms of achieving desired social and ecological outcomes. Of particular concern is that a serious and sustained focus on CWN continues to evade the majority of conservation practitioners and researchers. This "knowing-doing" gap (e.g., [18]) between the widespread recognition of the need to reconnect with nature (as a prerequisite for biodiversity conservation) reflects the general absence of this concept in conservation practice and, more generally, education. Is the task of reconnecting people with nature fundamental to and compatible with practices that deliver conservation outcomes? If so, is there sufficient understanding of $\mathrm{CWN}$ in conservation and sustainability education in terms of how it can be defined, practiced, and evaluated in order to foster ERB?

In introducing the field of conservation psychology, Saunders [19] outlines possible ways of organizing research areas within the field. This review draws on that format and explores theoretical, applied, and evaluative dimensions of CWN at the individual level (primarily)and the collective or group level. The paper, therefore, synthesizes a large cross-section of interdisciplinary literature to (1) review definitions, conceptualizations, and measures of CWN (theoretical); (2) cover activities and practices commonly associated with CWN (applied); (3) discuss possible ways to measure the success of strategies promoting CWN (evaluative); (4) highlight the benefits of CWN to human well-being and ERB; and, (5) emphasize the relevance of CWN to conservation by proposing avenues for its inclusion in common discourse and education so as to effect action $[4,20,21]$.

\section{Methods}

Three synergistic methods have been used to guide the literature search:

(1) Systematic Keyword searches of bibliographic e-databases: American Association for the Advancement of Science (CrossRef), American Psychological Association (APA), GoogleScholar, Life Sciences (JSTOR), MEDLINE (NLM), Nature Publishing Group (CrossRef), OneFile (GALE), SAGE Journals Online, ScienceDirect, Scopus and Web of Science. A three-step process was performed: i) using the words "nature" with the root "connect*" in the title, abstract, or keywords; (ii) searching for terms which may encompass CWN: "nature relatedness," "environmental identity," "ecological self," "place attachment," and "human-nature relationship"; and iii) subjectively screening results according to their perceived relevance to primarily conservation, psychology, and education disciplines, and they as pertain to CWN theory, application, and evaluation. 
(2) Snowballing An iterative process of using citations from the literature returned during the systematic search as an avenue for identifying further pertinent literature. Snowballing also included addressing those texts as identified through the subsequent peer-review process.

(3) Synchronicity (cf. [22, 23]) Giving due consideration to the literature which was coincidentally encountered (through e.g., peer recommendation, serendipitous discovery) at the "right time" and which found intuitive and meaningful resonance with salient questions at that stage of the review process. Given the multitude of ways in which human connections with nature can be addressed, this additional subjective filter helped prioritize an extensive list of search results.

Notions of CWN are also replete in informally published scholarly literature and stories of individuals' kinship with nature are common in many cultural accounts [24] as well as in the writings of those who have spent prolonged reflective time encountering the natural world [16]. Therefore, the literature review was broadened to include other scholarship to augment the scientific peer-reviewed literature [25]. Steps 2 and 3 were particularly helpful in identifying informally published literature, though it is accepted that pertinent texts may still be missing.

There is a general bias in literature toward Western conceptualizations of CWN, noting however that "Western" is an imprecise term which can be variously defined according to context. In this paper, we use "Western" to refer to the culture and philosophical tradition that has its historical roots in early European cultures (e.g., Greco-Roman, Germanic), Judaic and Christian values and Enlightenment thinking and that has shaped Anglo-European and North American society. This review, therefore, primarily focuses on CWN as relevant to persons socialized to middle-class Western values on the basis that it is widely accepted that the Western culture is largely responsible for fueling and exacerbating humanity's separation from nature (Table 1). However, since Western culture (and its discourse) has been exported through colonization and globalization, Western (and Westernized) worldviews are no longer geographically confined to Europe and its former colonies. In this regard, implications of this review are cross-culturally relevant, particularly since contemporary CWN draws much inspiration from non-Western (e.g., Eastern, Indigenous) traditions.

\section{Terminology}

"Nature" is largely a social-cultural construction and its conceptualization will vary across-and inevitably be influenced by-such contexts, including disciplinary epistemologies [26]. Readers should remain mindful of what is "nature" when reflecting on this review's implications. We use the term "nature" to refer to any element of the biophysical system which includes flora, fauna, and geological landforms occurring across a range of scales and degrees of human presence [27]. "Nature" may be therefore conceived as the biophysical environment as it exists without human beings. Yet this distinction remains problematic since it perpetuates the conceptual and perceptual human/nature divide [28]. However, for the purposes of approaching this review, it is a necessary demarcation.

An individual's ecologically desirable actions are described using a range of terms including: "pro-environmental behavior" (e.g., [29]); "environmentally responsible behavior" (e.g., [4]); "conservation behavior" (e.g., [19]); "ecological behavior" (e.g., [13]); and "sustainable behavior" (e.g., [30]). Here, we use the term "environmentally responsible behavior" (ERB) to capture these various terminologies. However, it is noted that "conservation behavior" is not necessarily synonymous with ERB.

The Oxford Dictionary [31] defines the verb "connect" [1. in relation to an object] as "to bring together or into contact so that a real or notional link is established; join together to provide access or communication," and [2. with no object] as "to form a relationship or feel affinity with someone" [31]. "Connect" originated from late Middle English (i.e., eighteenth century onward) to mean "be united physically" from the Latin connectere-from con (together) and nectere (bind). The Oxford Dictionary [31] definition for "reconnect" [1. to an object] is "connect back together" and [2. with no object] to "re-establish a bond of communication or emotion." This etymology informs understandings of CWN and points toward a communicative relationship involving a process of physical contact and/or emotional bonding.

"Reconnect," like other terms in the conservation lexicon (e.g., restore, rehabilitate, regenerate, reforest), implies a perceived loss and a quest to return to a more desirable, but often difficult-to-define, state. While some of these terms relate purely to ecological systems, "reconnect" (and "restore") may equally apply to the human-nature relationship. "Reconnect with nature" serves well as a generic call for behavior change; however, in contrast to the measurable state of CWN, it is action- and process-oriented, difficult to pinpoint as a measurable "state" and is therefore of limited use as scientific nomenclature.

Scholars may therefore refer to any of the following: "connectedness to nature" [13], "connectivity with nature" [32], "connection to nature" [33], "nature connection" [34], or "nature relatedness" [4]. We prefer "connectedness with nature" (CWN) instead of "connectedness to nature" because it evokes the subtle yet important idea that (1) humans are already an intimate part of 
Table 1 Types and drivers of the human (Eurocentric/Western) disconnect from nature

\begin{tabular}{|c|c|c|}
\hline & Psychological & Physical \\
\hline $\begin{array}{l}\text { Initial historical drivers } \\
\text { (severance/separation) }\end{array}$ & $\begin{array}{l}\text { Advent of language: (Greek phonetic) written word and } \\
\text { subject-verb-object grammar structure }[148,265] \\
\text { Adopting select interpretations of Judaism and } \\
\text { Christianity [28, 46, 266-268] } \\
\text { Ancient Greek philosophies, e.g., rationalism [41, 51, } \\
269] \\
\text { Cartesian dualism and deductive reasoning [7, 41, 43, 44, } \\
66,269,270] \\
\text { Enlightenment ideals of the educated mind }[55,270] \\
\text { Modernism and the disinterested sciences }[63,64,271] \\
\text { Loss of respect, humility, and empathy with nature [66] } \\
\text { General disenchantment of the universe }[1,37,63,66] \\
\text { General disenchantment of the universe }[1,37,63,66] \\
\text { Valorization of individual endeavor }[44,63]\end{array}$ & $\begin{array}{l}\text { Early civilization (abandoning 'the wild') [35, 272, 273] } \\
\text { Domestication of plants and animals [1, 35] } \\
\text { Totalitarian agriculture, land tenure, and ownership [1, } \\
274] \\
\text { Roman system of divide and rule [103] } \\
\text { Colonialism (and a logic of domination) [1, 41, 44] } \\
\text { Industrial revolution and a doctrine of progress [59, 62, } \\
63,241] \\
\text { Migration from rural to urban centers [39, 275] } \\
\text { Alienation from food sources (esp. meat) [28, 276] } \\
\text { Non-reliance/dependency on consumptive uses of } \\
\text { nature [59] } \\
\text { Adversarial nature, e.g., disease, fires, plagues, } \\
\text { earthquakes, and extreme climatic events [57] }\end{array}$ \\
\hline $\begin{array}{l}\text { Continual present-day } \\
\text { drivers (maintenance/ } \\
\text { perpetuation) }\end{array}$ & $\begin{array}{l}\text { Stronger, sharper ego "I" structure (than, e.g., non- } \\
\text { Western persons), individual-referenced identity, } \\
\text { limited self-concept }[277,278] \\
\text { Arrested development as a juvenile-like psychosis } \\
\text { [66, 273] } \\
\text { Embrace of mechanistic achievements ("Light") as } \\
\text { human triumphs over wild nature ("Dark") } \\
\text { [44, 63, 64, 124, 259] } \\
\text { Epistemic and disciplinary scientific divides (embodying } \\
\text { subject-object dualisms) [37, 41, 42, 268] } \\
\text { Rejection of non-Western ways of knowing [255, 279] } \\
\text { Technology-mediated lifestyles [43, 49] } \\
\text { Information and sensory overload [81, 85, 87] } \\
\text { "Environmental numbness," insulation from } \\
\text { environmental stimuli, sensory shutdowns } \\
\text { [262, 280, 281] } \\
\text { Environmental generational amnesia [69, 282] } \\
\text { "Shifting baselines" (in memory, perception) [283] }\end{array}$ & $\begin{array}{l}\text { Alienation from rural and wild environments }[3,7,55 \text {, } \\
\text { 160] } \\
\text { Scale (size and speed) of urbanization [284] } \\
\text { Poor design and development of the built environment } \\
\text { [284] } \\
\text { Physiological (survival) needs easily met (i.e., little } \\
\text { concept of the lower orders of 'Maslow's Hierarchy of } \\
\text { Needs') [173, 285]; } \\
\text { Exploitation of-and distancing from-animals [28, } \\
286] \\
\text { Indoor sedentary entertainment [8] } \\
\text { Television- and online-based environmentalism and } \\
\text { broadcasted documentaries [275, 287] } \\
\text { Extinction of experience (with nature) [69, 288] } \\
\text { Explosive population growth [289] } \\
\text { Globalization and multinational corporatism [218] }\end{array}$ \\
\hline
\end{tabular}

nature and (2) that the state imbues a sense of reciprocity and mutualism. In this paper, we use "disconnect" to refer to the physical and psychological (i.e., cognitive, affective, and experiential) separation from nature.

\section{The Disconnect from Nature}

The drivers of humanity's disconnect from nature have been extensively debated and documented [1, 3, 28, 35-48]. Drivers may fall into four different categories: (1) psychological severance; (2) physical severance; (i.e., events and trends that initiated the disconnect from nature); (3) psychological maintenance; and (4) physical maintenance (i.e., events and trends that perpetuate or exacerbate the disconnect from nature) (Table 1). All drivers are likely to have been influenced by-or are a result of - cultural norms or discourses [43]. The drivers may fit within more than one type, as one driver may function to cause disconnection in multiple ways; for example, technology-mediated lifestyles could fall into all four types, depending on context and how broadly "technology" is defined. Similarly, the physical driver's may stem from prevailing psychological mindsets; for example, colonialism as a result of a "logic of domination" [41] and historical drivers may still persist today (e.g., legacies of Ancient Greek, Cartesian, Enlightenment, and Modernist thinking). We have thus pragmatically classified according to which type of disconnect is, in accordance with common associations made in the literature, most likely a result of the respective drivers (Table 1). 
The call to reconnect seeks to overcome peoples' general perception as being separate from, and typically outside and above, nature and ecology (e.g., food-webs) [37, $41,49,50]$. This "blind spot"-that is, an inability to see oneself as part of nature and a denial of one's dependency on nature-is recognized as a key contributor to ongoing environmental destruction [4, 28, 41, 51]. More fundamentally, the human/nature "hyperseparation" embedded in the Western discourse is intimately linked to pervasive cognitive assumptions which split a unified reality into gendered dualisms (e.g., mind/body, reason/emotion, civilized/primitive, light/dark) - all of which tend to privilege the dominant former (masculine) over the latter (feminine) [41, 52-54]. Similar schisms are found within religion (as a separation theology with a masculine God removed from His creation (a feminine Earth)) and science (as a Cartesian-inspired separation ontology where nature (feminine) may be an object for detached human observation, possession, and control (masculine) [7, 55]).

The excessive subject/object partitioning of the world impedes people's ability to see or imagine connections between their thinking, doing, and being- a split that Spinoza already identified in the seventeenth century as being detrimental to a spiritual vision of the world [42, 56]. Mechanistic thinking was of measurable benefit to the biophysical sciences emerging during this period in the same way that dominionistic thinking enabled governments to offer citizens a degree of security and protection against adversarial nature (e.g., natural disasters and disease) [57, 58]. However, in both cases, such thinking and the values it supported was devastating to the human sense of belonging, mutualism, and connection with nature, earth, and the cosmos as a whole [58-60]. The perils of industrialization (as part of a doctrine of "progress" [61, 62]) and scientific rationalization on the human-nature relationship were also highlighted by the Romantic Movement of the eighteenth and nineteenth centuries [63], even though Romanticism itself has since been criticized for "fetishizing" nature as being unspoiled, wild and something to be admired from afar [61]. In any case, such resistance gradually gave way to Realism and was further displaced by burgeoning postwar consumerism, resource exploitation, and technologyreliant lifestyles fueled by a disenchanted capitalist-driven culture $[1,2,59,61,62,64-66]$. Some suggest that in losing contact with the poetry, archetypal myth, and symbolism of nature, we are creating a world devoid of meaning and further severing our connectedness with the planet $[61,67,68]$.

As people de-sensitize and/or adapt to these social and environmental changes, the (acceptable) reference point for measuring the extent of the human/nature disconnect is lowered with each generation [69].The cumulative result is the "extinction of experience": a devolution toward a largely unnoticed loss of regular, direct, and meaningful contact with nature [2, 19, 69]. This enlarges the "blind spot" concerning dependency on nature, can invoke fear and intolerance of certain species and has profound implications for ecologies, societies, economies, and human well-being [3, 5, 70]. We see this as a debilitating convergence of crises (or "polycrisis" [71]) driven by the perceptual disconnect from nature. Reference to perception alerts us to a problem that is intimately tied to consciousness (Box 1) [1, 51]. Understanding the human disconnect from nature as a problem in consciousness may yield valuable insight toward reconnecting.

Modern urban society is filled with potent stimuli: for example, electronic media and advertising which, in addition to creating an illusion of distance from nature [5], place constant demands on attention and the sensory field within consciousness $[85,87,88]$. We contend that persons increasingly suffer from inattention nature blindness as ecological phenomena are edited from conscious awareness in favor of this artificial "super stimuli" which contain more immediate compelling sensory and emotional content [89]. Inattention nature blindness reinforces peoples' perception as being separate from nature, since ecological phenomena no longer form a part of the experiences which shape consciousness. Westerners are more vulnerable to inattention blindness as they tend to fixate on focal objects, ignoring background and contextual information [89-91]. The implications are profound as this challenges assumptions about the universality of nature experience as well as the desired objectivity of scientific observation [92]. If we perceive what we look for, remaining blind to what else is present [93], then this directed attention away from nature may be central to the "crisis of perception" which, in turn, fuels a more fundamental crisis in consciousness. [94, 95].

Contemporary human consciousness is therefore being distracted to the extent that we remain entrapped in the mundane, unable to perceive the full spectrum of phenomena arising in nature $[1,51,63,95]$. This intimately ties back to the "extinction of experience": without the direct experience of nature needed to form an ecological consciousness, we cannot expect an ecological conscience which motivates care and action [51]. Reconnecting with nature therefore requires more than cultural reprogramming: it requires cultivating a consciousness that is attuned to the natural processes that have shaped human evolution over millennia. 
Box 1 Key concepts for consciousness and CWN

Despite scientific advances, consciousness, as a real phenomenon with a rational biological explanation, remains elusive, perplexing, and mysterious [60, 72-74]. The term "consciousness" is ambiguous since it is used across multiple contexts and with reference to multiple phenomena, (e.g., "awakeness," "to be conscious of something," "to know about something," or to refer to cognitive or attention capacity $[75$, p. 6]). For the purposes of this review, the following traits of consciousness are of specific relevance:

(1) Perception Perception may be understood as either primary sensory perception (the "experiencing self" [75] in the present) or secondary reflective perception ("remembering self" [75] in the past). Both types of perception are conventionally classified as cognitive functions since an individual's pre-existing cognitive concepts are used to frame, compare, and interpret incoming information which, in turn, form part of the complex process of mental model building in consciousness [76-78]. However, primary and secondary perception may have different but complementary applications for CWN, with primary perception mostly relying on embodied sensory awareness and secondary perception mostly employing conceptualized memory recall. In terms of CWN, it may therefore be more illuminating to make the distinction in consciousness as either [72]:

(i) Phenomenal: primary sensory perception in immediate experience as mediated by the body

(ii)Psychological secondary reflective perception in memory as mediated by conceptual processes of the mind (e.g., mental models and memory recall)

Despite being intimately entwined, both forms of perception should be considered when attempting to understand the disconnect from nature and the ways in which these forms perception might be influenced to cultivate a consciousness conducive to CWN

(2) Experience Consciousness is a product of an individual's accumulated diverse experiences—being conscious of the world allows one to survive in it, experience it, and endow it with meaning $[63,72-74,76,79]$. Experience, as it relates to consciousness and CWN, involves a personal encounter or event that is perceived and lived through; the senses organizing and interpreting stimuli (phenomena) in the external world $[63,76,78]$. Perception is a mode of human experience as well as a prerequisite for other forms of experience (e.g., bodily, imaginative) that form consciousness [73, 76]

(3) Attention Consciousness is always directed toward something. This self-willed intentionality-or directed attention-is the effortful, conscious process of utilizing cognitive resources to focus perception on selected stimuli, while filtering, diluting, or avoiding distraction from unrelated, irrelevant, or competing stimuli [27, 80, 81]. This determines what, how, and for how long a person gives something attention, whereby choices feedback and determine the content of everyday consciousness (i.e., experiences) [63]. Neuroscience demonstrates that an individual's focus of attention determines the strength of brain synapses and the size of cortex areas [82, 83].The capacity for humans to direct attention in this way appears to serve as (i) a coping mechanism to avoid the senses being overwhelmed and fatigued from all the stimuli (noise) in perceptual experience [76, 84-86] and (ii) an evolutionary tool allowing humans to pay attention to phenomena that may impact upon survival or involve problem solving, but which requires effort to sustain attention (e.g., listening for sounds of predators [63]). In both cases, considerable (mental) effort is required to resist distractions from more potent stimuli [81]

\section{Definitions and Conceptualizations of CWN (Theoretical)}

In following Saunders [19] suggestion for organizing conservation psychology research areas, this review first addresses theoretical and conceptual dimensions of CWN at the individual level. Multiple scholars have endeavored to describe or define CWN (e.g., [4, 7, 12, 13, 19, 32, 43, 96-101]). Descriptions of CWN vary according to the emphasis placed on the relative importance of the three key dimensions of cognition (e.g., perceptions, knowledge, and beliefs about nature and its relationship to one's sense of self) affect (e.g., feelings and emotions toward nature) and behavior (e.g., actions and experiences with/in nature) [102]. Since each of these dimensions interrelates and influences the other, CWN may be conceptualized as being an outcome of each-although often realized through a process of receiving information, having an experience, being affected, and finding connectedness, which may crystallize as commitment over time (Fig. 1).

Historically, numerous descriptions of CWN have been grounded in cognitive notions about one's relationship with nature and often based on the premise that knowledge of social-ecological interactions is sufficient to create a conservation ethic [102]. Most standard education and environmental awareness approaches have therefore focused on the provision of information about nature which is usually transferred though formal curricula, internet and media sources, field guides and may satisfy a curiosity or an urge "to know more" [103].While increasing research has called the effectiveness of such approaches into question [11, 29, 49], CWN nevertheless requires some cognitive dimensions. In this regard, a number of descriptions of CWN recognize the importance of an expanded self-construct which encompasses (and reciprocates with) all life-forms [7, 104]. For example, Schultz (e.g., [7, 24, 96]) sees CWN as the degree to which an individual includes (a knowledge structure of) "nature" within their identity or cognitive representation of "self" [102]. This closely aligns with concepts such as "environmental identity" [105] and "ecological self" which refer to the essence of oneself with which one readily identifies [12, 43, 104, 106].

More recently, the affective dimensions of CWN have been given greater attention (e.g., [13, 98, 101, 102, 107]) since it is has been found that that emotional connections are key predictors for environmental concern and ERB [13, 32, 102, 108]. Scholars have focused on different aspects of affect. For example, Mayer and Frantz [13] describe CWN in terms of Leopold's land ethic [9] and focus on dimensions 


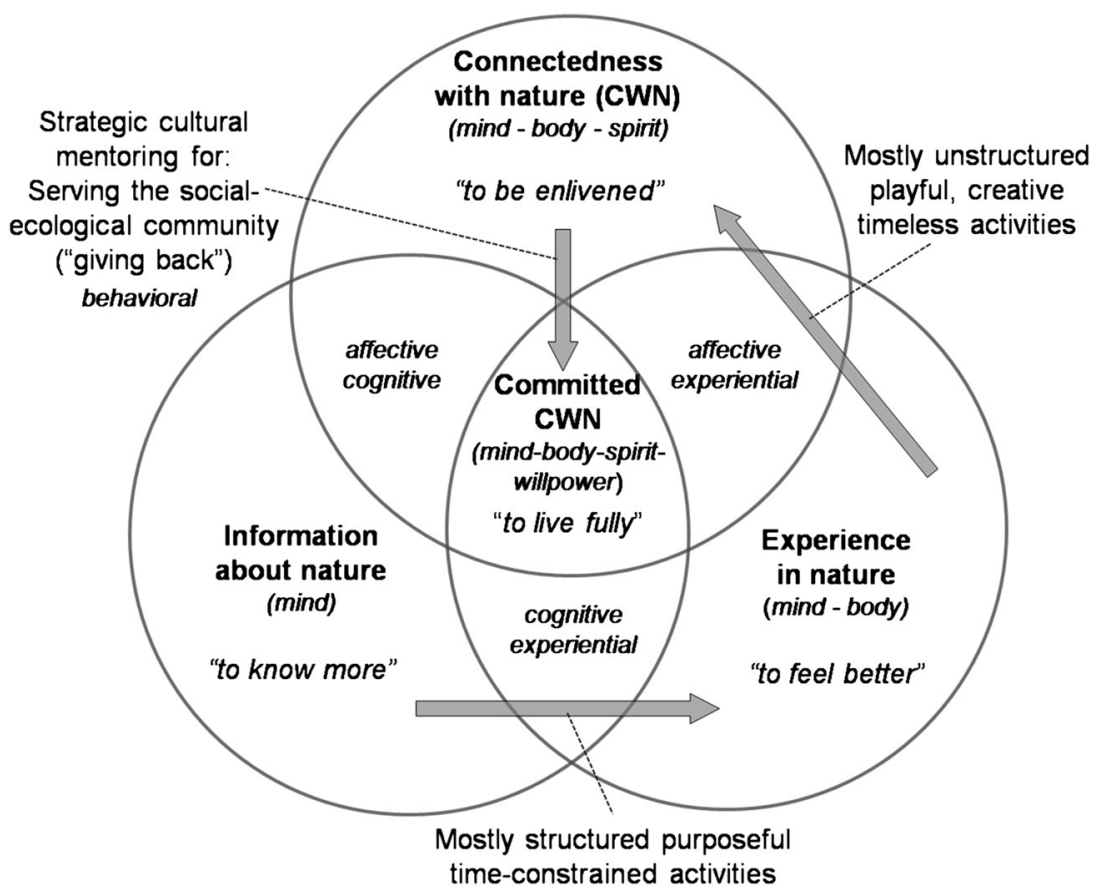

Fig. 1 Conceptual framework of key components comprising connectedness with nature $(\mathrm{CWN})$. Depicts $\mathrm{CWN}$ as comprising: information about nature; experience in nature; connectedness with nature; and committed connectedness with nature. Information about nature is primarily based on cognitive concepts, intellect, and information as obtained through education or media to satisfy the mind's curiosity and increase knowledge [103]. Experience in nature includes outdoor sports and recreation, facilitated eco-adventure and field trips, and is usually sought after to help the body and mind feel better or to support experiential learning [103]. Such activities are often (semi-) structured and constrained by time or have a particular purpose. In contrast, $C W N$ is often (unintentionally) realized through unstructured activities which

such as an individual's trait level of feeling emotionally connected and belonging to the natural community [99]. Kals et al. [98]. refer to emotional inclinations such as love, respect, and oneness with nature [7], while other researchers have given attention to the role of active care, sympathy, and empathy for nature $[109,110]$. All appear to have their place in terms of links with sensitivity to nature and ERB; however, it is equally clear that such feelings are intimately tied to direct bodily experience.

The experience of nature features heavily in the increasing research being done in areas of health promotion and wellbeing (e.g., [3, 27, 48, 111, 112]). Generally, experience in nature or contact with nature tends to be seen as encompassing outdoor sports, set recreational activities, nature-based tourism, eco-adventure and is usually pursued in order "to feel better" or receive physical gratification [103].Through field trips, experience in nature may also facilitate deeper cognitive understanding of information learned or received about nature. However, such activities tend to be mostly structured, purposefully targeted and/or constrained by time and context are free from strict time constraints or targeted outcomes. CWN arises through affective experience following, for example, extended nature immersion and may inspire and enliven one's spirit. Committed (or "deep") $C W N$ refers to the sustained embodiment of this tripartite as a behavioral set aimed at serving social and ecological communities through transformative leadership [34, 103]. According to Young [103], individuals may best achieve this committed (deep) $C W N$ through an intentional process of being strategically mentored as part of a culturally embedded process [103]. The conceptual framework (this figure) highlights that CWN requires balancing faculties of mind, body, and spirit (i.e., one's source(s) of inspiration) to generate willpower aimed at actualizing "self" and being of service to others

(Fig. 1). While a sense of CWN may unintentionally arise out of such physical-based activities, it is evident that the experiential dimensions of CWN may have a different quality and be characterized by being relatively unstructured, creative, playful, and acutely sensory aware. In focusing attention, such (in)activities cultivate a degree of stillness in the mind and body [103].

CWN therefore appears as a complex and veritable mix of synergistic information about feelings toward and experiences in or with nature (Fig. 1). Nisbet et al. [4]. recognize this with their multi-dimensional concept of nature relatedness which, in also drawing on the deep ecology notion of an "ecological self" [43, 45, 54, 104] blends cognitive, affective, and experiential connections with nature $[4,113]$. In terms of realizing $\mathrm{CWN}$, experience maybe most insightful, since it can involve the "dissolution of boundaries and a sense of a shared or common essence between the self, nature, and others" [27, p. 274]. Such meaningful experiences are capable of invoking strong affective responses as well as playing a 
pivotal role in reframing an individual's cognitive representation of their relationship with nature [63, 114-118].

Some people may encounter this as a transpersonal (e.g., spiritual) phenomenon [32, 54, 119-122]. In this regard, Beringer [123] points out that reducing the human relationship to nature as only conforming to the classical "AB-C" (affect-behavior-cognition) of psychology does not encompass the richness and ineffability of human experience which interpenetrates the rational and physical world. It is therefore argued that these soulful and spiritual aspects need to be identified, understood, and reconciled with conservation (science) as part of a necessary moral and ethical sensibility for confronting the convergent social and ecological crises driven by the disconnect from nature [39, 123-125].

Despite this rationale, "spirituality" nevertheless faces impediments for its inclusion in CWN conceptualizations. Firstly, ontological and epistemic contestations (e.g., conceptual views of reality) limit the extent that spirituality can be regarded as being distinct from (i.e., other than an emergent property of) the accepted $\mathrm{A}-\mathrm{B}-\mathrm{C}$ dimensions of an individual's consciousness. Secondly, while spirituality may form an integral part of a person's CWN and contain nature-based transcendental components [120], spirituality may not necessarily be a prerequisite for establishing some level of CWN. This assertion is made largely on the basis that, in Western discourse, the term "spirituality" is confounded by a multitude of layered meanings; individuals may not consider their CWN as having a spiritual component even though they may express their relationship to nature in a way that suggests otherwise. Given that spirituality is often understood as denoting an "other-worldliness" defying scientific or rational explanation [120, 124], spirituality tends to be either dismissed as a serious topic for discussion or avoided because common interpretations of spirituality do not align with personal definitions or experiences. To bypass such roadblocks in terms of defining CWN, we prefer to use "spirit" instead of "spirituality" to refer to that which serves as an individual's source of inspiration [126]. ${ }^{1}$ On this basis, CWN may be distinguished by its ability to awaken one's "spirit" and induce an "aliveness" that is considered a common and desirable trait of CWN, as a result of being consistently in

\footnotetext{
${ }^{1}$ The etymology of "spirituality" is related to the Latin spiritus meaning "soul, courage, vigor, breath" and spirare "to breathe" [296]. "Inspiration" is therefore the act of 'breathing in,' to be animated by something of power (e.g., 'God') [297]. In terms of CWN and spirituality, it is also important to distinguish between: spiritual ethos/belief (primarily cognitive); spiritual experience (primarily affective); and spiritual practice (primarily experiential and behavioral) as symbiotic components of one's "spirituality" [115].
}

touch with, appreciative of, and inspired by nature (Fig. 1) $[34,103]$.

Researchers note that CWN is more than a fleeting "warm feeling" experienced after spending time outdoors $[48,102]$. As Nisbet et al. [4].see it, CWN comprises feelings and thoughts that include an appreciative understanding of the interconnectedness of life as well as experiences and behaviors that exhibit action and agency toward the environment. The latter points to the importance of sustained commitment in that CWN should ideally consist of less transient and more enduring (i.e., stable) states of $\mathrm{CWN}$ over time. In this sense, a committed CWN refers to the willed embodiment of cognitive, affective, experiential, and connections with "spirit" as part of a behavior set which aims to "give back" (or "pay it forward") through leadership in service of social-ecological communities (Fig. 1; Table 3) $[103,127]$. According to Young [127], individuals are likely to only achieve this "deep" CWN through an intentional process of being strategically mentored as part of a culturally embedded (i.e., community based) process [127] (Table 3). Literature comprising this review generally does not delineate between $C W N$ and committed $C W N$; it is, however, an important distinction to make as ultimately personal well-being and the motivation for ERB rests on a sustained sense of CWN that balances faculties of mind, body, and spirit with willpower. This review uses CWN to refer to this more enduring state; however, it is noted that the measures, indicators, and practices outlined later in the paper may not always be referring to the same.

Attempts to produce a definitive and fixed definition of CWN are idealistic and may even border on arrogance, particularly since a sense of CWN is very personal [120]. However, in synthesizing the literature above, the following characterization of $\mathrm{CWN}$ is proposed: $\mathrm{CWN}$ is a stable state of consciousness comprising symbiotic cognitive, affective, and experiential traits that reflect, through consistent attitudes and behaviors, a sustained awareness of the interrelatedness between one's self and the rest of nature. CWN is more than the simple contact or superficial enjoyment of nature: it is an enduring appreciation, empathy, and mindfulness of the intrinsic value and shared essence of all life-including non-(aesthetically) appealing and non-(apparently) useful elements to humans: that is, it transcends hedonism, speciesism, and functional utilitarianism. CWN manifests as a commitment to action (i.e., a resolve to respect and take responsibility for conserving nature) $[4,48,101,113,128,129]$.

\section{Measuring and Quantifying CWN (Empirical)}

Since the 1970s, psychological research has been investigating relationships between various predictor variables 
Table 2 Instruments used for measuring (aspects and traits of) connectedness with nature (CWN)

\begin{tabular}{ll}
\hline Instrument & Reference (Author, Year) \\
\hline Emotional Affinity toward Nature (EAN) & Kals et al. 1999, [98] \\
New Environmental Paradigm (NEP) (revised) & Dunlap et al. 2000, [290] \\
Inclusion of Nature in Self (INS) & Schultz 2001, [134] \\
Environmental Identity Scale (EIS) & Clayton 2003, [105] \\
Implicit Associations Test (IAT) (modified) & Schultz 2004, [12] \\
Connectedness to Nature Scale (CNS) & Mayer and Frantz 2004, [13] \\
Connectivity with Nature Scale (CwNS) & Dutcher et al. 2007, [32] \\
Nature Relatedness Scale (NRS) & Nisbet et al. 2009, [4] \\
Love and Care for Nature (LCN) & Perkins 2010, [291] \\
Connection to Nature Index (CNI) & Cheng and Monroe 2010, [101] \\
Disposition to Connect with Nature (DCN) & Brügger et al. 2011, [292] \\
Nature Connectedness Inventory (NCI) & Ernst and Theimer 2011, [139] \\
Dispositional Empathy with Nature Scale (DENS) & Tam 2013, [100] \\
\hline
\end{tabular}

and measures of environmental concern, attitude, and behavior [11, 130]. Despite CWN's long-standing theoretical presence in philosophical and environmentalist literature, attempts to empirically distill, isolate, and refine the CWN construct for the purposes of psychological testing have only gained momentum since the turn of the millennium [32]. This newfound focus has been coupled with the growing realization that (1) environmental attitudes, concerns, beliefs, and behaviors alone are insufficient in explaining individuals' relationships with nature and their motivation behind ERB [4]; (2) while efforts to understand individuals' ERB have tended to focus on personality, knowledge, and skills as predictors [4, 131], it is motivation (as a complex blend of implicit and explicit attitudes, beliefs, intent, values, norms, locus of control, personality traits, and knowledge influenced by internal and external factors $[11,12,88,132])$ which drives individual behavioral choices [11, 49, 131]; and (3) CWN can influence motivation and be a core motivation in itself. For example, CWN has been found to be a primary motivation for conservation volunteers to engage with projectswhich, in turn, sustains their contact with nature [133]. CWN was the core motivation for inspiring Dutch forest managers to carry out their work since their personal and professional actions were embedded in a CWN which transcended the individual and represented an "ultimate concern" for wanting to manage forests effectively [122]. Altogether, the prospect that CWN may help foster ERB has motivated environmental psychologists to develop corresponding measures [7].

The human relationship with the natural world is deeply entwined with the conscious and subconscious mind and is therefore difficult to access for scientific analysis [3]. Similarly, assessing CWN is challenging, since an individual's worldview may not be well developed and their sense of CWN is not always given conscious consideration or is readily available for retrieval [12]. However, in recent years, various instruments have been developed which aim to measure CWN or a suitable proxy (Table 2). The more frequently cited instruments in the literature include Emotional Affinity toward Nature (EAN) [98]; Inclusion of Nature in Self (INS) [134]; Environmental Identity Scale (EIS) [105]; Connectedness to Nature Scale (CNS) [13]; and the Nature Relatedness Scale (NRS) [4, 7]. The INS, CNS, and NRS are briefly expanded upon here.

The INS is a single-item instrument designed to measure the degree to which an individual includes nature as part of their identity [96, 102]. The conceptual model behind the INS recognizes 'inclusion' as consisting of a sense of connection (cognitive); a caring response (affective); and a commitment to action (behavioral) [28, 96, 102]. The INS invites participants to express their CWN by choosing one of seven diagrams that depict pairs of circles (i.e., one circle representing 'Self' and one representing 'Nature') with varying degrees of overlap.

The CNS is a 14-statement single-factor instrument measuring an individual's conscious, stated level of affective relatedness, and kinship with nature [27]. The CNS seeks to operationalize Leopold's "land ethic": that is, a perceived and affective sense of belonging to the natural community and a cognitive representation of "self" that includes the natural world, such that harm to nature is experienced as harm to self $[9,135]$. The CNS is designed to overcome shortcomings identified with earlier CWN measures (Table 2) as well as providing an avenue for bringing less research-oriented discussions of CWN into the more research-oriented realm of psychology [13]. The CNS has been shown to be a reliable predictor for ERB (including identifying oneself as an environmentalist) and 
Table 3 Selected competences and practices for cultivating connectedness with nature (CWN) at the individual and collective level

\begin{tabular}{|c|c|c|c|}
\hline Level & Competences & Practices for cultivating competences & Literature \\
\hline \multirow[t]{12}{*}{ Individual (personal routines) } & Quiet mind & Still for extended introspection/sits in nature & \multirow{12}{*}{$\begin{array}{l}{[28,34,166-} \\
168,170,171 \\
268,293]\end{array}$} \\
\hline & Awareness & Engage and expand natural survival senses & \\
\hline & Attentiveness & Focus on nature signs: tracks, calls, phenology & \\
\hline & Interaction & Touch nature to foster subject-subject view & \\
\hline & Sense of place & Know your area: map, wander, sit, explore & \\
\hline & Curiosity & Practice inquisitive questioning, reflection & \\
\hline & Appreciation & Cultivate awe, wonder, gratitude for nature & \\
\hline & Creativity & Do art, poetry, story, music, imagination, play & \\
\hline & Problem solving & Experiment and improvise for self sufficiency & \\
\hline & Green care & Participate in nature-based therapy, farming or exercise & \\
\hline & Holistic perspective & See reality as interconnected, reciprocated & \\
\hline & Attunement & Awaken to/harmonize with earth's language and wisdom & \\
\hline \multirow[t]{10}{*}{$\begin{array}{l}\text { Collective/Group (social- } \\
\text { cultural fabric and systems } \\
\text { of governance) }\end{array}$} & $\begin{array}{l}\text { "Invisible school" \& } \\
\text { Social networks }\end{array}$ & $\begin{array}{l}\text { Recreate a supportive community-based cultural fabric for } \\
\text { ecological learning, e.g., mentorship, nature-based schools, } \\
\text { outdoor education and family centered activities }\end{array}$ & {$[34,47,264]$} \\
\hline & $\begin{array}{l}\text { Citizen science/NGO } \\
\text { participation }\end{array}$ & $\begin{array}{l}\text { Promote civic engagement with field-based ecological research, } \\
\text { with a secondary aim to cultivate naturalist intelligence and } \\
\text { inquiry }\end{array}$ & {$[49,264]$} \\
\hline & $\begin{array}{l}\text { Sustained service to the } \\
\text { community }\end{array}$ & $\begin{array}{l}\text { Endorse selfless actions which, in showing appreciation of } \\
\text { ecology and the web of life, acknowledge that individuals } \\
\text { have autonomy in developing a sense of identity in order to } \\
\text { play their role or function in their 'niche' in serving the } \\
\text { community at large }\end{array}$ & $\begin{array}{c}{[2,34,47,88} \\
135,264]\end{array}$ \\
\hline & $\begin{array}{l}\text { Eco-literacy and } \\
\text { environmental } \\
\text { education/action }\end{array}$ & $\begin{array}{l}\text { Formulate education programs which fuse human and natural } \\
\text { histories, and blend arts and sciences toward nature } \\
\text { appreciation }\end{array}$ & {$[2,264]$} \\
\hline & Land ethic & $\begin{array}{l}\text { For issues of social and ecological importance, center public } \\
\text { dialog on a Leopoldian land ethic }\end{array}$ & {$[2,9]$} \\
\hline & $\begin{array}{l}\text { Community justice/ } \\
\text { equality }\end{array}$ & $\begin{array}{l}\text { Empower responsible systems which place human rights, and } \\
\text { community-based equity at their core }\end{array}$ & {$[2]$} \\
\hline & Local focus & $\begin{array}{l}\text { Encourage place-based environmental decision-making to be } \\
\text { locally informed and monitored in partnership with a central } \\
\text { (governmental) agency }\end{array}$ & {$[2]$} \\
\hline & $\begin{array}{l}\text { Consensus-based } \\
\text { decision-making, } \\
\text { environmental dialogs }\end{array}$ & $\begin{array}{l}\text { Work toward a system of consensus decision-making, whereby } \\
\text { consensus is the gradual process of building both } \\
\text { understanding and commitment, which has been achieved } \\
\text { through dialog that has satisfactorily ensured all perspectives } \\
\text { were considered }\end{array}$ & {$[2,294]$} \\
\hline & $\begin{array}{l}\text { Ecological restoration/ } \\
\text { reconciliation }\end{array}$ & $\begin{array}{l}\text { Repair and rehabilitate areas of natural value, for reasons } \\
\text { ecological, economic and cultural. Reinstate ecosystem } \\
\text { resilience (as a basis for social resilience) }\end{array}$ & {$[2,69]$} \\
\hline & $\begin{array}{l}\text { Collective action (with } \\
\text { social norms and } \\
\text { discourses) }\end{array}$ & $\begin{array}{l}\text { Employ social marketing tools and techniques (e.g., using } \\
\text { commitments, norms, prompts, goal setting, incentives, } \\
\text { motivational messages and social diffusion) to shape the } \\
\text { prevailing social norms and discourses such that they align } \\
\text { with CWN and promote ERB and collective action }\end{array}$ & $\begin{array}{l}{[19,29,30,49,} \\
295]\end{array}$ \\
\hline
\end{tabular}

subjective well-being (including improved life satisfaction, overall happiness, perspective-taking abilities, and resolution abilities for interpersonal problems and moral dilemmas) $[7,13,136]$. While primarily a trait measure, the CNS has also been adapted to measure CWN as a "state" response to situational factors, such as exposure to different external environments [102, 136]. Shortcomings of the CNS have been identified, including its inability to fully measure affective and experiential dimensions of CWN as intended [4, 130]. The CNS, like the INS, appears more a 
measure of an individual's cognitive beliefs about their CWN but which taps into affective aspects $[4,130]$. Nevertheless, the CNS's test-retest consistency and correlation to other related instruments (Table 2) support its reliability and validity [13].

The NRS is a 21-item 3-factor "trait-like" measure claimed to be a more complete construct, overcoming limitations of the CNS and measuring more than environmentalism, activism, cognitive beliefs, and superficially pleasing facets of nature [4]. It includes elements concerning physical interaction, comfort level, and familiarity with nature as well as active commitments and personal responsibility toward mitigating impacts on the environment [128].The NRS has been found to be valid and internally consistent, temporally stable and correlated with time spent outdoors, in nature, and with measures of environmental attitudes and behaviors [4]. The NRS significantly predicts subjective hedonic well-being as well as eudaimonic well-being (i.e., meaning of life, positive functioning as related to, for example, personal growth, purpose in life and positive relations with others) [7, 137]. People scoring higher on the NRS (i.e., nature-related persons) are usually more open to experience, agreeable, and conscientious [4].

Despite various authors (e.g., $[4,13])$ investigating intercorrelations between different CWN measures as a way to support the reliability and validity of their own constructs, the potential convergence (e.g., overlap in labels, scale items) or divergence (e.g., whether different aspects of CWN are captured) of CWN constructs (Table 2) has only been recently examined empirically [7]. Tam [7] finds that the convergence of multiple CWN measures (Table 2) allows for CWN to be considered as a broad latent construct in itself, whereby findings can be discussed within one integrated CWN framework (as opposed to only focusing on separate associations with specific measures). In aiming to select the appropriate CWN measure, researchers can be reassured that correlations with variables will be of similar direction and magnitude across all measures [7]. However, the divergence found between measures shows that they are not identical and, specifically, highlight that measures which are multidimensional (e.g., EIS, NRS) and which can tap into cognitive and affective dimensions of CWN (e.g., NRS, LCN, and possibly INS and CNS) will perform better [7]. These findings highlight that while CWN may have many unique meanings and traits (i.e., multi-dimensional), it shares a common foundation [7]. CWN measures could possibly be further improved by including dimensions of collective identity (as conceived in social psychology and sociology literature) [7, 138].

The instruments outlined above and those reviewed by Tam [7] have generally been designed for adults, although some (e.g., CNS) include adaptations for older children [102, 139]. Converting CWN instruments for use with children is problematic as statements and concepts used within various scales contain language and subtle nuances that may be beyond the comprehension of most children [102]. Two measures explicitly developed for children are the connection to nature index (CNI) [101] and the nature connectedness inventory (NCI) [139]. Both instruments draw on Mayer and Frantz's [13] approach: the CNI's 4-factor trait instrument was influenced by their definition of CWN along with other studies on environmental attitudes, while the NCI's 11-item scale addressed the same areas underlying Mayer and Frantz's CNS [13] with additional items examining children's feelings about nature [101, 102, 139]. Survey questions that ask children about their feelings toward nature, rather than their concepts of connectedness have been found to be more successful when testing such instruments [102]

In applying any CWN measure, researchers need to remain aware of three potential limitations. Firstly, like all self-report measures, there is inherent uncertainty in the validity of the results produced. For example, participants may need to have an explicit belief about their relationships with nature readily available for retrieval and report without bias $[12,140]$. Secondly, in noting the tendency for many CWN studies to draw on sample populations from undergraduate (often psychology) student populations [4, $7,13,107,141-143]$, it is possible that this may constitute a non-representative sample group with specific dispositions toward CWN $[12,26]$. Thirdly, the validity and transferability of CWN measures are limited by the geography of research in this field, which is primarily focussed on North America. The possibility that both the conceptual and empirical basis of the CWN construct may not be as applicable to other cultural groups is rarely made explicit, despite research highlighting cross-cultural differences in CWN [21, 144-146]. The way people experience and connect with nature is influenced by demographics (e.g., life-stage and transferability of middle-class U.S. values and lifestyle choices [147]); geographies (e.g., varying opportunities for contact with nature [7] ); and culture and language (differing conceptual constructs and collective ways of expressing the human-nature relationship [148, 149]). People from different cultures will also vary in how they understand, interpret, and express themselves when responding to surveys [7]. We caution that Westerndeveloped scales tested on Western-socialized individuals cannot assume compatibility with non-Western groupslanguage and comprehension differences aside.

In addition to recommending increased community and cross-cultural testing, we suggest that these quantitative CWN measures be complemented with qualitative techniques as part of a mixed methods approach (cf. [150]) for 
broadening and deepening the understanding of $\mathrm{CWN}$. Qualitative meaning always forms the context for the quantitative and may help give insight into how knowledge, perceptions, or emotions toward nature is transformed into action [151, 152]. Incorporating phenomenological explorations alongside natural and social science methods may capture the experience and essence of CWN as it is meaningfully lived [63, 79, 121, 153, 154]. However, an individual's ability to convey what a sense of CWN feels like or means to their life may be constrained by the limitations of language and their ability to describe it $[63,120,148]$.

In this light, understandings and measures of $\mathrm{CWN}$ will continue to evolve. In distilling current knowledge across interdisciplinary literature, we recommend that refining and applying CWN measures will be oriented by an appreciation that CWN is the extent to which an individual's thoughts (e.g., reflective perceptions, conscious, or implicit attitudes or cognitive beliefs) and actions (e.g., instinctive, reflexive, reasoned, or cultural practices) embody the relatedness between themselves and nature and reflect a sense of personal responsibility, respect, and reverence for all life over various temporal and spatial contexts.

\section{Practices and Strategies for CWN (Applied)}

As proposed by Saunders [19], the second type of research in conservation psychology is the applied component of identifying effective strategies; in this case, fostering CWN. Little empirical attention in the scientific literature has been given to context-specific strategies, practices, and actions which may be effective in helping individuals or groups cultivate CWN.

Saunders [19] suggests that, in addition to creating better conceptual models (about, e.g., the relationship between CWN and ERB), more applied research is needed to identify strategies which cultivate care and concern for nature. Such progress has been made with research on, for example, significant life experiences [152, 155-157], restorative qualities of nature $[85,87,141,158]$ environmental identity and place attachment $[38,105,144,159$ 161], and wilderness journeys [87, 117, 119, 162-164]. Keniger et al.'s [59] 2013 interdisciplinary review is a helpful addition with their typology of the indirect, incidental, and intentional interactions between people and nature. The authors note that the intent behind the interaction may be pivotal in whether or how ERB is realized $[11,59,141]$. Few of these studies focus on the types and qualities of activities which may be replicated over time and space in order to foster CWN. However, a substantial body of literature related to the practice of CWN (although not always termed as such) may be found across diverse disciplines and in both scientific and informal scholarly literature. Disciplines such as ecopsychology and outdoor education have made particular advances in this applied field.

Since CWN comprises cognitive, affective, experiential, and possibly spiritual aspects, an effective suite of practices should target each of these fields of human consciousness. It is difficult to partition or classify activities according to these areas since a given activity may appeal to multiple faculties, depending on personal and situational contexts. In this respect, we again follow Saunders' [19] typology and summarize CWN activities as they relate to caring/ valuing nature at both the individual and collective level (see Table 3 for a more complete list).

At the individual level, CWN practices are often encountered as part of (semi-)structured workshops and/or reflective retreat settings. These events, usually naturebased, are possibly inspired by deep ecology (including, e.g., depth psychology, emotional releasing, eco-spirituality) Eastern-style relaxation and mindfulness (e.g., yoga, meditation, breath-work), Indigenous worldviews, rites and traditions (e.g., vision quests, shamanism) and/or any (neopaganesque) combination of these $[43,54,165]$. Semistructured CWN practices or spontaneously arising opportunities (e.g., through unstructured activity) may form part of wilderness journeys; outdoor adventure activities; ecotourism; environmental/sustainability education and interpretation; nature-guided therapy, spiritual/ cultural/religious gatherings or celebrations and their inherent ritual/prayer/ceremony; community, seasonal or environmental festivals (and including creative arts such as drawing, dance, music, drama, play); environmental activism; community gardening; and voluntary simplicity/ eco-lifestyle movements [43, 165]. Within many of these contexts, nature is understood as the teacher, healer, or inspiration, while the outdoor educator, guide, or facilitator is tasked to enable, cocoon, or help manifest learner's insights and experiences [166].

Shaw [166] provides an overview of a typical CWN process with key practices (see also Table 3). Many begin with simple "loosening-up" exercises to relax and bring awareness to the breath and body, followed by further exploration and awareness of the human senses as part of directing perceptual focus and attention back to one's self and the natural world [34, 51, 165, 167, 168]. These practices may be followed by sitting silently, recording observations (often creatively or artistically) and reflecting on the experience [166]. Participants may be encouraged to interact or commune with elements of nature or wildlife as part of a search for personal symbolism, messages, and meaning [166]. Personal rituals or expressions of thanks to nature may be performed and, finally, participants' might be encouraged to share their stories and insights with their fellow learners [166]. Many of these activities draw 
participants out of their comfort zones or engage faculties of their being (usually the phenomenal aspects of consciousness (Box 1)) which are under-utilized in daily life. Activities may foster intense personal introspection or close bonding with peers-that is, connections with self, nature, people, and/or spirit [115].

CWN may also be (often less intentionally) achieved through more conventional means. Hands-on involvement in ecological restoration can be particularly beneficial in fostering $\mathrm{CWN}$, since it involves an attentiveness to nature in an active embodied way, engaging body and mind and absorbing the wisdom inherent in the restoration process [69, 85, 88, 160]. Similarly, experiential citizen science may serve as a vehicle for promoting CWN, and increasing the likelihood people will engage in ERB [49]. The rise of social media is supporting a proliferation of "apps" which may enhance eco-literacy by encouraging people to identify, record, and report their nature sightings. As part of a balanced "screen diet" [169], nature-focused apps may serve as an important initial step in turning people's attention toward the nature around them. Cultivating conventional naturalist skills such as bird-watching, plant drawing and identification, ecological mapping (including sounds), animal tracking and acute, silent observation can all be highly beneficial activities for finding CWN [34, 170]. These exercises can bring people into closer contact with wildlife, which has also been shown to help foster CWN [28, 116].

Some of these practices for individuals (or small groups of individuals) might also fall under the umbrella of "green care" as outlined by Hine [171]. Green care initiatives usually consist of a facilitated therapy or intervention (e.g., therapeutic horticulture, animal assisted interventions, care farming, green exercise as a treatment, and eco-, nature-, or wilderness-therapy) for a particular participant(s) (i.e., there may be person-specific needs or outcomes in mind) [102].

At the collective or group level, Pyle [2] addresses CWN by offering a blueprint for governance through a sixpoint "nature matrix." The nature matrix is primarily embedded in a Leopoldian and biophilia ethic and, while an explicit statement on the desired outcomes is lacking, reference is made to broad-scale, community-based restoration efforts, mass campaigns for promoting ecological literacy and, a cultural shift beyond capitalism's obsession with perpetual growth [2]. Pyle [2] see these basic tenets, alongside nature-based people's desirable way of being, as necessary for a "radical reconnection." The nature matrix is a call-to-arms for policy-makers, although few will likely have the courage, knowledge, or political wherewithal to initiate such bold changes [2]. Pyle admits that the nature matrix may be utopian but that it is nevertheless "a model for essential, incremental change, a dream whose eventual adoption may enhance chances for reconnection and for ecological survival itself" [2, p. 206]. Based on the premise that humans are "wired" for connection and belonging (see below), it follows that the design of an appropriate socialcultural fabric should enable a process of CWN to unfold automatically [103].

This incremental but vital process requires engagement across all sectors [19]. Intermediary organizations (e.g., schools, universities, NGOs, community groups), educators, mentors, and families will need to play a prominent role in bridging the individual and group progress toward CWN [34] (Table 3). This will require stakeholders to find collaborative ways of overcoming identified challenges for reconnecting. For example, England's Natural Childhood Inquiry revealed that an unreasonable health and safety culture; traffic dangers; the rise of indoor entertainment; finding time and space for nature in schools; receding access to quality green and natural spaces; and socio-economic and cultural factors are the key barriers preventing or limiting childhood CWN [102, 172]. It is therefore necessary that local groups (including schools and higher educational institutions) are supported to become catalysts for local action, thus enabling all citizens (and students) to have meaningful engagement with nature [172].

Practices outlined in this section are neither exhaustive nor static. For example, Naess [105, p. 140] lists 25 other ways (i.e., behaviors) that supporters of deep ecology "can joyfully adapt their lifestyle to the movement" with many of these orientations clearly aligned with (outcomes of a) deepening CWN. Therefore, the above section serves to introduce common themes which might be seen as necessary in fostering authentic CWN. They may help to balance, mitigate, and make sense of undesirable events, patterns, and changes in one's life. Ideally, CWN practices help persons awaken to a deeper appreciation, care, compassion, and empathy with nature-realizations of such connections are at the essence of true systems thinking [135].

\section{Measuring Success (Evaluative)}

As Saunders [19] conceived it, the third research area for conservation psychology is evaluative (i.e., measuring success). This is also where the scientific literature seems to fall short. Given that there is little evidence for implementation of CWN strategies in practice (in either conservation or formal education), it follows that there is little information on their effectiveness in the instances where CWN strategies or practices may have been systematically applied [139]. While valuable evaluative research on the effect of (semi-)structured experiences in nature exists (e.g., [87, 117, 119, 157, 162, 163, 168, 173-178], there 
appears to be a paucity of literature which (1) specifically targets the CWN construct as part of an intervention or implementation strategy; (2) has clearly defined a priori indicators on what constitutes "success"; (3) has sufficient evidence as to whether CWN programs are achieving results [43]; (4) identifies CWN threshold levels for precipitating desired levels of ERB; or (5) is based on longitudinal analysis. Empirical research and evidence-based criteria are needed to address these current shortfalls.

Evaluative indicators for CWN may be extracted from existing quantitative instruments (Table 2). The 21 statements in the NRS offer a range of cognitive, affective, and experiential traits which provide useful points of reference. For example, after engaging with CWN activities over time, do persons: go outdoors more often (even in unpleasant weather); take more notice of nature around them; feel more comfortable in wilderness areas; feel more aware about environmental issues; and give greater consideration to how their actions affect the environment? Similarly, the INS, which uses overlapping circles to depict one's cognitive representation of self in relation to nature, may provide reliable feedback on how a persons' perception of their inclusiveness with nature has changed over time (e.g., in response to $\mathrm{CWN}$ practices). The potential of existing CWN scales to measure progress in CWN is largely beyond dispute-many were developed with this goal in mind. However, for the purposes of effective evaluation for an individual or groups of individuals, the content comprising these measures needs to be made explicit, along with weak areas (i.e., statements registering low scores) in participant responses so activities can be adapted to improve the effectiveness of the CWN (intervention) strategy. Note also that since existing CWN measures are self-report, persons may be unaware of ways that they have changed (in favor of CWN) even though such traits may be evident to others.

Evaluative indicators may need to be more qualitative, particularly as they relate to education and learning outcomes. If CWN is recognized as being fluid, holistic, and personal, then it follows that the means of assessing success must be equally so. To this end, Young et al. [31, p. 258] propose indicators ("natural, vibrant, vital, and sustainable criteria") which while not comprising a strictly quantitative assessment, instead act as radical beacons for orienting and assessing successful education outcomes which serve to inform three core fields of learning: awakening sensory awareness; cultivating knowledge of place; and restoring the human bond with nature [34]. These all contribute to fostering a "naturalist intelligence" [cf. 205, 206].

Evaluative indicators for CWN may also be aligned with the associated well-being benefits described below. Heightened CWN may be recognized in persons displaying attributes and traits of personal growth and health and wellbeing (e.g., inner happiness, peace-of-mind, presence-ofbeing, heightened attention and awareness, love and forgiveness, aliveness and vitality, curiosity and inquisitiveness, physical and mental resilience, generosity and gratitude, empathy and feelings of belonging, relatedness, and oneness [32, 97, 100,101, 127, 137, 153, 179, 181]).

As indicated in the theoretical conceptualization of CWN, a level of consistency and commitment is required. This continuity also implies that an individuals' CWN is transferable between contexts even when the context is less favorable or appealing. This differentiates between persons exhibiting CWN with those who are more prone to biophobia [182] or inclined to only seek out aesthetically pleasing nature or have a preference for charismatic species [183]. Finally, "continuity" also implies that CWN is relatively resilient to external shocks, stressors, or adverse situations (e.g., natural disasters) over varying temporal and spatial scales.

Actions and behaviors will need to comprise any evaluative indicator set, although CWN may not always be reflected in an individual's everyday actions [4, 13]. Fundamentally, behaviors should move beyond transient instrumental actions which might be motivated by tangible (e.g., economic incentives) or egoist (e.g., social status/ image) concerns. It is expected that salient qualities of CWN would encourage individuals to embrace "voluntary simplicity" in reducing their ecological footprint (e.g., consumption levels) [88]. This lifestyle choice has long been advocated as a necessary step toward ecological sustainability and human well-being [184]. Conversely, fulfilling commitments and incremental actions consistent with CWN may become operationalized as a regular behavior (i.e., habit) which, in turn, reinforces the cognitive and affective associations with CWN and further shapes an ecological consciousness [11, 28, 185]). Ultimately, at the collective level, a community of enlivened appreciative individuals living with social-ecological sensitivity and purpose may indicate an emerging culture of connectedness.

CWN is not a prescribed formula, blueprint, or roadmap. Neither is it a seamless unidirectional "onward and upward" path toward utopian being: fluxes (as ebbs and flows) and cycles are intrinsic to life itself. As a deeply personal and a uniquely experiential endeavor, CWN is necessarily nuanced by time, space, and contextual variables. The process may be characterized by sustained practice which can result in sudden progressive shifts or, alternatively, prolonged periods of relapse but which may nevertheless be valuable as "regressions in service of future expansion and integration" [66, p. 163]. In all cases, there is much scope for investigating the reliability, validity, and applicability of potential indicators as 
contextual understandings of $\mathrm{CWN}$ and its relevance to conservation and education evolve.

\section{Benefits of CWN}

Numerous studies and reviews illustrate that contact with natural environments is beneficial as measured by multiple variables pertaining to physiological, emotional, mental, social and spiritual health, and well-being [3, 27, 48, 59, $88,102,108,111,113,121,186,187]$. In their typology of the benefits from interaction with nature, Keniger et al. [59]. illustrate the vast diversity and range of benefits: from individuals factors such as improved cognitive, cardiovascular and immune functioning [3, 27] to collective benefits such as reduced crime, aggression, and antisocial behavior [3, 113]. These effects, especially the therapeutic and restorative effects of nature on humans [3, 27, 85, 121, $158,171]$, are often linked back to the biophilia hypothesis and/or Attention Restoration Theory [27, 81, 85, 102, 107, 113].

Researchers find that green outdoor settings reduce symptoms of attention-deficit/hyperactivity disorder (ADHD) in children significantly more than activities conducted in built outdoor or indoor settings [188, 189]. Green space settings have been found to positively influence (inner city) children's level of creative play [190] and the naturalness of views of nature from home predict selfdiscipline (e.g., children's performance on tests of concentration, impulse inhibition, and delay of gratification) [191]. In these latter studies, vegetation cover and naturalness of the view could be used as predictors for outcomes. This may have implications for CWN.

Nature exposure does not necessarily translate to CWN (Fig. 1); however, various studies show CWN constructs to be positively correlated to similar variables pertaining to physical and psychological well-being (e.g., mindfulness, meaningfulness, self-actualization, happiness, and vitality) [13, 99, 107, 113, 136, 159, 168, 178]. Under certain conditions, CWN acts as a trigger for spiritual, self-transcendence, and unifying experiences [28, 47, 87, 153, 154, 192]. CWN is considered causal in generating psychological benefits because of the "power of the feelings associated with belonging to a community or something 'greater than oneself'" [26, p. 129]. In this sense, nature has a transformative value as it appears that humans become their highest selves when they "stretch out" of themselves and appreciatively value others (i.e., nonhumans). [118, 193] CWN seems to also offer a "distinct happiness benefit" in that it remains a unique and independent predictor when controlling for other powerful subjective connections (e.g., social bonds) and predictors of happiness [113]. Overall, CWN appears to make our lives happier and more purposeful, fulfilling, and meaningful [4, 99].

While these well-being benefits are sufficient motivation in themselves to encourage individual engagement with nature, the litmus test for CWN's relevance to conservation is the extent to which it can foster ERB, as a prerequisite for influencing social norms, and inspiring collective action $[19,49]$. A number of studies suggest that affective experiences in nature can predict ERB [32, 98, 121, 141, 159, 194]. The direct experience of engaging with nature facilitates emotional bonding and stronger behavioral consistency toward the object [88, 195]. As a positive emotional experience, CWN can initiate changes in cognitive or perceptual processes and, when embedded in feelings of relatedness beyond self (i.e., an "ecological self" which broadens identity formation to include nature and associated biospheric value concerns [88, 196]), CWN presents a platform for ERB as part of a sense of personal obligation to bring such feelings into everyday life practice $[12,13,24,88,122]$. These affective connections have been shown to be an independent predictor of intentions to engage with nature [98, 159], including children's intention to participate in nature-based activities in the future [101]. While it is possible that ERB also promotes CWN (i.e., they are mutually reinforcing) [139], empirical research demonstrates CWN to be a strong predictor for sustainable attitudes, concerns, motivations, actions, and lifestyles even when controlling for other attitude measures which do not include a sense of connectedness [4, 7, 13, 49, 108, 113, 160]. For example, a recent study found that CWN was a stronger motivation for visiting parks and interacting with green space than simply having the opportunity to do so [108]. ERB is more likely when a person's "heart is in it" [49, p. 299] — and the heart usually engages through direct sensorial and emotive experience. Wilson (in [19]) advises that we would be wise to listen to the heart-and to then act with rational intent.

According to the conceptualizations of CWN as outlined in this review, there appears to be few detriments of CWN (for Westernized persons) as identified in the literature. While one may have psychologically and genetically predisposed fears toward certain elements of nature as part of humanity's entwined evolutionary history with the natural world [182, 198], it would be erroneous to confuse this biophobia as a negative aspect of CWN. While one may still (innately) fear or dislike certain phenomena in nature, CWN gives context and perspective to biophobic reactions in accordance with understandings implicit in CWN, for example, inclusiveness, relatedness, and the associated respect and reverence held for all life.

Perhaps the greatest scope for adverse effects associated with CWN is in witnessing the desecration of nature and experiencing the trauma, grief and despair associated with 
that (e.g., when a place of profound childhood significance is destroyed or when one is forcibly removed from areas to which one had an emotional and/or spiritual attachment) [199, 200]. However, in reviewing literature on how afflicted children cope in the face of conflict and disasters, Chawla [201] finds substantial evidence to support the buffering, therapeutic, and healing effects of nature and that memories of a deep connection with nature during childhood were a "fund of calm" which could be drawn upon later in life to help (re)discover self and (re)imagine new futures (e.g., [202-205] ). Such benefits are also concomitant to the adaptive processes (across multiple levels, e.g., physical, psychological, social-cultural, and institutional functioning) which are necessary to form and sustain resilient systems [201].

\section{CWN in Conservation: Possible Avenues for Integration}

Knowing the value of CWN is insufficient in its utility for conservation-it must be applied in doing conservation [8, 18, 206, 207]. Francis Bacon (1561-1626) and Neo-Confucian philosopher Wang Yang-Ming (1472-1528) imagined the same when they suggested that "good knowledge" is that which combines knowledge with action [208, 209]. If one knows they should implement an action, and does not do so, then their knowledge is incomplete and they do not truly know: "Knowing is the beginning of action, and doing is the completion of knowledge" [211, p. 29]. Despite what we know, the action of CWN receives little attention in the scientific literature and the insights that are available in fields such as ecopsychology and outdoor learning rarely find their way into conservation mainstream. This is partly because conservation biology has struggled to effectively integrate and prioritize social (e.g., psychology) processes for research and practice $[49,210$ 212], in curricula at universities [213] and/or because of the handicaps imposed by the "boundaries of our disciplinary homes and frameworks" [21, p. 137]. Using the concept of CWN to implement more effective conservation actions underscores the need for interdisciplinary thinking, collaboration, and transdisciplinary approaches which, in bridging science and society, may more effectively inform conservation practice and education [19, 214-217].

Conservation psychology was conceived with the aim to "create stronger connections between the natural and social sciences, between research and practice, and between psychology and the other social sciences" [21, p. 137]. This emergent field is envisaged to consist of two interlinking and mutually reinforcing research streams aimed at understanding (1) How humans behave toward nature with the goal of ERB and (2) How humans care about/value nature with the aim of creating harmonious relationships and an environmental ethic [19, 193]. In this conceptualization, "Personal connections to animals, places, ecosystems etc." is placed as central to the stream of "caring/ valuing nature" and involves research aimed at encouraging individuals to bond with elements of nature through understanding, for example, experiential and emotional connections, environmental identity, values, and ethics [19]. At the group level, this research stream seeks to establish a rich and compelling human-nature language which is capable of changing social-cultural norms and discourses [19]. Clearly, CWN finds a home here. CWN may help move conservation beyond paradigms which constrain its effectiveness, in both theory and practice. The following paragraphs identify five general areas of opportunity:

(1) CWN may answer a call for more compelling language in conservation [16, 19] Conservation efforts aimed at fostering ERB have largely focused on information-rich campaigns which are often poorly conceived and targeted, given that knowledge about an issue alone is unlikely to change behavior [11, 29, 30, 49, 132]. Conservation has generally excelled in articulating ecological crises [210]. While this knowledge and awareness are necessary, an overemphasis on biodiversity loss (e.g., "gloom and doom" campaigns which may resemble Christian narratives of an imminent Apocalypse requiring humanity to repent their ecological sins [218]) and other crisis-driven scenarios is failing to improve the effectiveness of conservation initiatives or motivate an indifferent public [69, 136, 219-221]. Individuals may respond to negative messages invoking guilt and fear but the eventual outcome may be denial, frustration, and disempowerment [69]. The perception of "crisis" may even make people more conservative and change resistant [218]. People may thus be more motivated to conserve nature when presented with understandings of how CWN contributes to health and well-being [113]. Because the benefits of CWN are available to all persons, language used in communication can be tailored to be more inclusive. This may be more effective in engaging the public and might counter environmentalism as being perceived as only a "special interest" [222].

(2) CWN may build hope and resilience The crisis addiction mentality pervading sectors of the conservationist community resembles "post traumatic embitterment disorder" - a violation of basic beliefs resulting in feelings of bitterness, unfairness, and hopelessness and a conviction that the world, not 
them, must change [223, 224]. This "conservation grief" has been facetiously compared with KüblerRoss' five stages of death and dying [225, 226]. Since a desire to protect nature without CWN may hinder well-being, the benefits of CWN may buffer the distress accompanying an awareness of environmental crises or serve as a reserve of inspiration to be drawn upon in times of hardship [113]. As Thomashow [200] recommends, the combination of intimate experiences with nature and deep selfreflection is necessary to the "wisdom training" needed to liberate the anger and despair often associated with environmental neglect and destruction. Yet many environmentalists are unwilling to confront such emotions because they are unaware of how to do so [200]. In providing such an avenue, CWN can cultivate more positive feelings for how we practice conservation and, in bettering ourselves, ultimately, inspire change in others. There is always a need to balance hope with realism [227]; however, alongside the promotion of "know-how" and behavior alternatives, CWN (as part of a placed-based education) remains critical in ensuring success in conservation $[6,221,228] .^{2}$

(3) CWN may constitute a more enduring and farreaching motivation for ERB CWN promotes more than instrumental actions aimed at fostering ERB. This is important because it cannot be assumed that perceived ERB in one area of a person's life is driven by motivations which will be transferred to other lifestyle choices, and thus fail to reproduce similar ERB outcomes or capture an overall "netgain." This is particularly relevant in the face of transient economic incentives or other short-term benefits. Rather than educators or decision-makers being forced to choose between instrumental (behavior change) and emancipatory (human development) strategies [229], promoting a CWN rooted in direct affective experience is likely to motivate and empower environmental awareness and ERB across the board [88, 173, 197, 230]. Given these prospects, along with the other potentials outlined in this review, CWN presents itself as more than just

\footnotetext{
2 Note that notions of connection in conservation science are already commonplace, although these usually refer to "ecological connectivity" [298-300] which is concerned with protecting, restoring and improving ecological processes to build resilience in the face of external stressors [301]. However, as part of efforts to bridging disciplinary terminology and seek shared and inclusive understandings, CWN could also be conceived as restoring and improving physiological and psychological processes to build personal resilience in response to stressors associated with urban life or being a conservationist in a time of ecological crisis.
}

another "conservation fad" [cf. 231] and more of a moral and ethical sensibility. CWN may provide an accepted avenue for tackling "the big fuzzies." A 2011 survey of scientists' opinions revealed a concerning dichotomy: while understanding human interactions with nature was ranked as the highest priority for conservation planning, the role of spiritual, cultural, and utilitarian values as reasons to conserve biodiversity were ranked poorly [232]. This is precarious, because it disconnects science from value-laden practice-a practice that must be inclusive if it is to be successful. This is a process of finding out "who speaks for nature" [233] and acknowledging that other ways of knowing and relating to nature may be more appropriate under specific contexts. However, doing so is likely to invoke "big fuzzy concepts": that is, issues where values and ethics are difficult to define, access, and measure, and therefore tends to be avoided by conservationists [234, 235].The risk in this approach is that it may undermine "conservation opportunism" [236] since spiritual and cultural components of CWN may be powerful motivations for conserving nature in certain contexts [228]. Many writings have investigated the role of religion and spirituality in supporting the conservation of bio(cultural) diversity and the role of science and education therein [125, 237-242]. Such discussions broach issues not usually discussed in mainstream conservation: for example, sacred connections with land, the spirit of place, the role of ritual (including religious ceremony) in nourishing earth and ourselves, and how vicarious childhood experiences opens paths toward CWN in adulthood [155, 165, 202, 243, 244]. While such topics still sit uneasily at the fringe of the natural sciences, $\mathrm{CWN}$ may provide the necessary framework and language through which diverse perceptions, emotions, and experiences of nature may be scientifically legitimized, accounted for and harnessed for effective conservation practice.

(5) CWN is intrinsic to evolutionary perspectives of humans and the natural world The call to "reconnect with nature" is often grounded in the realization that human evolution is intimately tied to the natural environment since, throughout most of history, humans have subsisted in wild and rural areas by hunting, gathering, herding and, more recently, producing with agriculture [59, 160]. Such notions are not new to science and the Origin of Species [245] inextricably tied humans to nature through biology and genetics, presenting a new perspective of an interconnected world [63]. However, Darwin's 
view was rooted in a physical, and usually tangible, reality and was less forthcoming on the psychological ways in which humans have evolved with nature. In environmental literature, the biophilia hypothesis presented a significant breakthrough in this realm by contending that humans are biologically and psychologically predisposed to affiliate with the natural world $[3,7,57,246,247]$.

Biophilia describes the connections that humans instinctively seek with the rest of life as an innate love or affection [246] or, alternatively, as a learned responsibility for nature [247]. While these traits may be neither strictly innate nor acquired, fixed, or universal [248], research shows that dimensions of human biophilia are also shared with living non-human primates [249]. Non-human primates are keenly attuned to their natural habitat, experts at deriving value from it and "display a propensity for emotional learning and kinship" [44, p. 16]. It is therefore clear that the evolutionary experience of humans involves nature and "we are therefore predisposed to resonate with these surroundings, consciously or not" [26, p. 121].

Finally, psychology research demonstrates peoples' basic and evolutionary need to "belong" as a valued member of a community: group identity (e.g., with family, friends, neighbors, social networks, special interest communities) provides a sense of purpose and facilitates connection to people and place [13, 27, 160, 250, 251]. Our burgeoning engagement with social media may represent one way through which this connection and belonging is sought [252]. This thirst for new forms of social connection is perhaps also a subconscious attempt to fill a psychological emptiness resulting from a growing physical separation from nature [197]. CWN compels us to consider our evolutionary needs-from inseparable ecological and social perspectives [253].

\section{Educating for CWN: A Radical but Relevant Prerequisite for ERB}

The rationale for endorsing CWN in (conservation) education follows logical argumentation:

(1) Fundamental to conservation biology is conservation practice [49, 254];

(2) Conservation practice understands and positively influences human behavior [19, 49, 211];

(3) Behavior is determined by a complex blend of internal and external factors [11, 49, 88, 132];

(4) Internal factors are driven by motivations within which environmental values and beliefs are keythat is, those correlating with specific environmental attitudes or biospheric and intergenerational concerns [12, 32];

(5) Environmental values and biospheric concerns are associated with the degree to which individuals perceive and feel themselves as being interconnected with all life $[24,32,146]$;

(6) Individuals who possess these values and believe themselves to harbor CWN are more likely to find motivations for adopting ERB and conservation action [13, 32, 49, 133];

(7) Promoting and educating for $\mathrm{CWN}$ can therefore foster effective conservation practice [102].

Accepting this logic is to equally accept that $\mathrm{CWN}$ is a core concern of conservation biology, psychology, and education. It represents a truly interdisciplinary process and endeavor.

Some may consider that the theory and practice of CWN resembles a return to pre-scientific animism and an idealization of our hunter-gatherer roots. This is confrontational to formal contemporary education systems that have consistently rejected non-Western ways of knowing [255, 256]. Pyle [2, p. 209], however, believes that "Reconnecting with nature is not a matter of reversing the fall, getting back to Eden, or approximating the peaceable kingdom. These states never occurred." Clearly, a return to idealized subsistence living is near impossible since we cannot unlearn all we now know (about, e.g., human developmental potential), reverse technological advancement, restore ecological integrity or recreate the strong social bonds which supported old formulas that were more pertinent when the world was very different to now $[88$, 257, 258].

Similarly, CWN may seem to reinvent a Romanticism which, while emphasizing strong personal relationships with nature, may have instead contributed to a distancing of human-nature relations [61, 63]. While contemporary views seek to reassert the corporeality and earthliness of life (rather than the ethereal) [63, 259], such associations remain threatening to belief systems that might view CWN as an "ersatz religion" [cf. 172]. White [46] pursued a similar aim decades ago: rather than seeking to eject Christianity, he sought a viable equivalent to animism which carried a message of stewardship, humility, and care for creation [40].Ultimately, this is not a question of exchanging one way of life for another but instead invites an opening up to the potentiality which can be harnessed from established points of reference [258].

In the context of conservation education, it appears that "The only reconnection that will be truly significant must also be radical" [2]. "Radical" is relative and therefore ambiguous but it is evident that humans need to rediscover a "consciousness of place" that recognizes a living interconnected 
earth, yet retains scientific credibility $[88,221]$. A scientifically validated avenue toward embarking on this radical process might best begin with consciously shifting perception, attitudes, and behavior to align with statements contained within CWN measures (e.g., CNS, NRS). This may instigate a cognitive shift toward perceiving relatedness, interdependency, and eventually, intuiting or feeling a part of the web of life [260]. However, we can no longer rest with the hope that CWN may only be realized through intellect. At a minimum, experiential education for CWN should encompass sensory awareness and emotional bonding through nature- and placebased immersion - indeed this might be the only way in which perceptions can be transformed [88, 221,261]. CWN might be viewed as a "natural sensory science" which, as a trans-discipline, integrates behavioral and perceptual development with (environmental) education, (human) ecology, and (eco)psychology as part of a conservation renaissance [167, 262].

A thirst for knowledge and empirical evidence should not stifle progress: we know enough to act with fervor. Waterhouse [263, p. 1090] recommends: "Find a place in the natural outdoor world and just be there for an hour" and "find your spot to watch and listen to nature, in solitude, and reconnect." Environmental education has long sought to promote ERB but has only achieved limited success [17]; CWN promises more effective and enduring outcomes [12, 63, 98, 230]. However, expertise from conservation science, psychology and education may be critical in providing the practical "know-how" (e.g., training) to support and translate CWN into action [62, 175, 209]. In all cases, CWN appears an essential vehicle for implementing effective stewardship measures now and into the future [8]. As Swaisgood and Sheppard [6, p. 95] ask "If people don't connect with nature, where will our next generation of environmental stewards come from?"

This review emphasizes the need to prioritize CWN in conservation discourse. It demands reflection on the cognitive, affective, and experiential dimensions of CWN when designing education strategies and curricula [173, 180, 264]. It urges dialog on CWN conceptualizations, activities, and indicators to guide effective implementation. It invites exploration on the types of meaningful nature experiences that are capable of grounding CWN in childhood and cultivating it throughout adulthood [115, 202, 244]. It also presents itself as a radical but necessary call for conservation and education professionals to promote the theory (knowing) and embody the practice (doing) of CWN as a precursor for both ERB and enhanced wellbeing. Doing so should enable these persons to become better role models and sources of inspiration for sustainable living; after all, if conservationists cannot commit to CWN, who will [6]? Ultimately, the call to reconnect with nature invites a response in individual and collective consciousness: an intentional and experiential process aimed at revitalizing the human-nature relationship.

Acknowledgments Thank you to Melissa Hatty, two anonymous reviewers, and the handling editor for detailed comments and valuable input on earlier drafts; the Wildlands Studies Australia 2012 class for helpful reflections on CWN, particularly to Guido Chiappa and Ilana Copell; the DST-NRF Centre for Excellence in Invasion Biology which funded the overarching $\mathrm{PhD}$ research; and TsamaHUB's Transdisciplinary Doctoral Programme in Sustainability (Stellenbosch University) which housed this $\mathrm{PhD}$ research.

\section{References}

1. Scull J (1999) The separation from more-than-human nature. http://members.shaw.ca/jscull/separate.htm. Accessed 27 June 2011

2. Pyle RM (2003) Nature matrix: reconnecting people and nature. Oryx 37:206-214

3. Maller C, Townsend M, St Leger L et al (2008) Healthy parks, healthy people: the health benefits of contact with nature in a park context: a review of relevant literature, vol 104. Deakin University and Parks Victoria, Melbourne

4. Nisbet EK, Zelenski JM, Murphy SA (2009) The nature relatedness scale: linking individuals' connection with nature to environmental concern and behaviour. Environ Behav 41:715-740

5. TEEB (2010) The Economics of Ecosystems and Biodiversity: Mainstreaming the economics of nature: a synthesis of the approach, conclusions and recommendations of TEEB, vol 39. UNEP, Nairobi

6. Swaisgood RR, Sheppard JK (2011) Reconnecting people to nature is a prerequisite for the future conservation agenda: response from Swaisgood and Sheppard. Bioscience 61:94-95

7. Tam K-P (2013) Concepts and measures related to connection to nature: similarities and differences. J Environ Psychol 34:64-78

8. Balmford A, Cowling RM (2006) Fusion or failure? The future of conservation biology. Conserv Biol 20:692-695

9. Leopold A (1949) A sand county almanac. Oxford University Press, New York

10. Chawla L (1999) Life paths into effective environmental education. J Environ Educ 31:15-26

11. Kollmuss A, Agyeman J (2002) Mind the gap: why do people act environmentally and what are the barriers to pro-environmental behaviour? Environ Educ 8:239-260

12. Schultz PW, Shriver C, Tabanico JJ, Khazian AM (2004) Implicit connections with nature. J Environ Psychol 24:31-42

13. Mayer F, Frantz C (2004) The connectedness to nature scale: a measure of individuals feeling in community with nature? J Environ Psychol 24:503-515

14. Holling CS (1986) Resilience of ecosystems: local surprise and global change. In: Clark W, Munn R (eds) Sustainable development of the biosphere. Cambridge University Press, Cambridge, pp 292-317

15. Tidball KG (2012) Urgent biophilia: human-nature interactions and biological attractions in disaster resilience. Ecol Soc 17:art5

16. Reser JP (2003) Thinking through "conservation psychology": prospects and challenges. Hum Ecol Rev 10:167-172

17. Zelezny L (1999) Educational interventions that improve environmental behaviors: a meta-analysis. J Environ Educ 31:5-15

18. Knight AT, Cowling RM, Rouget M et al (2008) Knowing but not doing: selecting priority conservation areas and the researchimplementation gap. Conserv Biol 22:610-617 
19. Saunders CD (2003) The emerging field of conservation psychology. Hum Ecol Rev 10:137-149

20. Winter D (2000) Some big ideas for some big problems. Am Psychol 55:516-522

21. Wilhelm-Rechmann A (2011) Using social marketing to bridge the gap between systematic conservation planning and implementation at the local government level. Nelson Mandela Metropolitan University, Port Elizabeth

22. Jung CG (1960) Synchronicity: an acausal connecting principle. In: Hull RFC (ed) Bollingen Ser XX From Collect Work CGJung. Princeton University Press, Princeton

23. Main R (2007) Revelations of chance: synchronicity as spiritual experience. State University of New York Press, Albany, p xi, 259

24. Schultz PW (2000) Empathizing with nature: the effects of perspective on taking concern for environmental issues. J Soc Issues 56:391-406

25. Mouton J (2001) How to succeed in your Master's and Doctoral Studies: A South African guide and resource book. Van Schaik Publishers, Pretoria

26. Atran S, Medin D (2008) The native mind and the cultural construction of nature. MIT Press, Cambridge

27. Bratman GN, Hamilton JP, Daily GC (2012) The impacts of nature experience on human cognitive function and mental health. Ann N Y Acad Sci 1249:118-136

28. Vining $\mathbf{J}$ (2003) The connection to other animals and caring for nature. Hum Ecol Rev 10:87-99

29. Wilhelm-Rechmann A, Cowling RM (2008) Social marketing as a tool for implementation in complex social-ecological systems. In: Burns M, Weaver A (eds) Exploring sustainability science: A South. African perspect. African Sun Media, Stellenbosch, pp 179-204

30. McKenzie-Mohr D, Smith W (1999) Fostering sustainable behavior: an introduction to community-based social marketing. New Society Publishers, Gabriola Island

31. ODO (2012) Connect/reconnect. In: Oxford Dict. http://oxforddic tionaries.com/definition/connect?q=connect. Accessed 7 July 2011

32. Dutcher DD, Finley JC, Luloff AE, Buttolph Johnson J (2007) Connectivity with nature as a measure of environmental values. Environ Behav 39:474-493

33. Luck GW, Davidson P, Boxall D, Smallbone L (2011) Relations between urban bird and plant communities and human wellbeing and connection to nature. Conserv Biol 25:816-826

34. Young J, Haas E, McGown E (2010) Coyote's guide to connecting with nature, 2nd edn. Owlink Media, Shelton

35. Katcher A, Beck A (1987) Health and caring for living things. Anthrozoos 1:175-183

36. Axelrod L, Suedfeld P (1995) Technology, capitalism, and Christianity: are they really the three horsemen of the eco-collapse? J Environ Psychol 15:183-195

37. Bernard PS (2007) Re-uniting with the Kosmos. J Study Relig Nat Cult 1:109-128

38. Ashwell AN (2010) Identity and belonging: urban nature and adolescent development in the City of Cape Town. School of Education, University of Cape Town, Cape Town

39. Higgins P (1996) Connection and consequence in environmental education. J Adventure Educ Outdoor Leadersh 13:34-39

40. Palmer JA (2001) Fifty key thinkers on the environment. Routledge, London

41. Griffin N (2001) Val Plumwood. In: Palmer JA (ed) Fifty key thinkers Environ. Routledge, London, pp 283-289

42. Van Breda J (2008) Overcoming the disciplinary divide: towards the possibility of a transdisciplinary hermeneutics. In: Burns M, Weaver A (eds) Exploring sustainability science: A South. African perspect. African Sun Media, Stellenbosch, pp 91-134

43. Baille R (2003) Applied ecopsychology in Australia: approaches to facilitating human-nature connections. Gatherings 8. http:// www.ecopsychology.org/journal/gatherings8/. Accessed 3 Nov 2012

44. Plumwood V (1991) Feminism and the mastery of nature. Routledge, New York

45. Mathews F (1991) The ecological self. Routledge, Milton Park, Oxon

46. White L (1967) The historical roots of our ecological crisis. Science 155:1203-1207

47. Louv R (2005) Last child in the woods: Saving our children from nature-deficit disorder, 2008th edn. Algonquin Books, Chapel Hill

48. RSPB (2013) Connecting with nature: finding out how connected to nature the UK's children are. Sandy, Bedfordshire

49. Schultz PW (2011) Conservation means behavior. Conserv Biol 25:1080-1083

50. Plumwood V (2008) Being prey. In: Remebering Val Plumwood. http://valplumwood.files.wordpress.com/2008/03/beingprey.doc. Accessed 28 June 2013

51. Cohen M (1997) Reconnecting with nature: finding wellness through restoring your bond with the earth. Ecopress, Corvallis

52. Hattingh JP (2005) Environmental philosophy and ethics: a critical overview of anthropocentric, ecocentric and radical value positions. In: Loubser CP (ed) Environmental education: some South African perspectives. Van Schaik Publishers, Pretoria, pp 72-97

53. Greenway R (2011) Can a bigger map save us? A commentary on Esbjörn-Hargens and Michael Zimmerman's Integral Ecology: uniting multiple perspectives on the natural world. Ecopsychology 3:159-163

54. Booth AL (1999) Does the spirit move you? Environmental spirituality. Environ Values 8:89-105

55. Barlett PF (2008) Reason and reenchantment in cultural change: sustainability in higher education. Curr Anthropol 49:1077-1098

56. Macdonald PS (2001) Benedict Spinoza. In: Palmer JA (ed) Fifty key thinkers environment. Routledge, New York, pp 44-50

57. Kellert SR, Wilson EO (1993) The biophilia hypothesis. Island Press, Washington, DC

58. Combs A, Holland M (1996) Synchronicity: science, myth, and the trickster, 2nd edn. Marlowe \& Company, New York

59. Keniger LE, Gaston KJ, Irvine KN, Fuller Ra (2013) What are the benefits of interacting with nature? Int J Environ Res Public Health 10:913-935

60. Sheldrake R (2012) The science delusion: freeing the spirit of enquiry. Hodder \& Stoughton, London

61. Fowler-Smith L (2013) The importance of perception to environmentalism. In: Davis S (ed) Peer-reviewed papers. Balanceunbalance 2013 international conference on May 31-June 2, 2013, Noosa, Australia. Biosphere Limited \& CQUniversity, Noosa, pp 50-63

62. Berry T (1988) The dream of the earth. Sierra Club, San Francisco

63. Morse M (2011) River experience: a phenomenological description of meaningful experiences on a wilderness river journey. School of Geography and Environmental Studies, University of Tasmania, Hobart

64. Oelschlaeger M (1991) The idea of wilderness: from prehistory to the age of ecology. Yale University Press, New Haven

65. Hamilton C (2010) Consumerism, self-creation and prospects for a new ecological consciousness. J Clean Prod 18:571-575

66. Metzner R (1995) The psychopathology of the human-nature relationship. In: Roszak T, Gomes ME, Kanner AD (eds) Ecopsychology restoring earth, healing the mind. Sierra Club Books, San Francisco, pp 55-67

67. Fuller P (1988) The geography of mother nature. In: The iconography of landscape: essays on the symbolic representation, 
design and use of past environments. Cambridge University Press, Cambridge

68. Van der Post L (1978) Jung and the story of our time. Vintage, New York

69. Miller JR (2005) Biodiversity conservation and the extinction of experience. Trends Ecol Evol 20:430-434

70. Lemelin RH (2013) Introduction. In: Lemelin RH (ed) Management of insects in recreation and tourism. Cambridge University Press, New York, pp 1-20

71. Morin E (1999) Homeland earth. Hampton Press, London

72. Chalmers D (1996) The conscious mind: In search of a fundamental theory. Oxford University Press, London

73. Searle JR (1997) The mystery of consciousness. The New York Review of Books, New York

74. Schneider S, Velmans M (2007) Introduction. Blackwell companion to conscious. Blackwell Publishing, Oxford

75. Kahneman D (2010) The riddle of experience vs. memory. In: TED.com. http://blog.ted.com/2010/03/01/the_riddle_of_e/. Accessed 9 Sept 2012

76. Jacobs M (2006) The production of mindscapes: a comprehensive theory of landscape experience. Socio-spatial analysis group, Wageningen University, Wageningen

77. Biggs D, Abel N, Knight AT et al (2011) The implementation crisis in conservation planning: could mental models help? Conserv Lett 4:169-183

78. Maund B (2003) Perception. Acumen Publishing Limited, Chesham

79. Van Manen M (1990) Researching lived experience: human science for an action sensitive pedagogy. SUNY Press, Albany

80. James W (1892) Psychology: The briefer course. Holt, New York

81. Kaplan R, Kaplan S (1989) The experience of nature: a psychological perspective. Cambridge University Press, New York

82. Stefan K, Wycislo M, Classen J (2004) Modulation of associative human motor cortical plasticity by attention. J Neurophysiol 92:66-72

83. Heron J, Roach NW, Whitaker D, Hanson JV (2010) Attention regulates the plasticity of multisensory timing. Eur J Neurosci 31:1755-1762

84. Huxley A (1954) The doors of perception. Chatto \& Windus, London

85. Kaplan S (1995) The restorative benefits of nature: toward an integrative framework. J Environ Psychol 15:169-182

86. McCallum I (2005) Ecological intelligence: rediscovering ourselves in nature. Africa Geographic, Cape Town

87. McDonald MG, Wearing S, Ponting J (2009) The nature of peak experience in wilderness. Humanist Psychol 37:370-385

88. De Lange WJ, Nahman A, Reed L, Mahumani B, Nortje K, Audouin M (2010) Contributions from the social sciences to understanding and changing consumer behavior: a literature review. CSIR, Pretoria

89. McRaney D (2011) You are not so smart. Dutton, Penguin Group (USA) Inc., New York

90. Chua H, Boland J, Nisbett R (2005) Cultural variation in eye movements during scene perception. Proc Natl Acad Sci 35:12629-12633

91. Masuda T, Akase M, Radford MHB (2008) Cultural differences in patterns of eye-movement: comparing context sensitivity between the Japanese and Westerners. J Pers Soc Psychol 94:365-381

92. Starbuck WH (2006) The production of knowledge: the challenge of social science research. University Press, Oxford

93. Simons D, Chabris C (1999) Gorillas in our midst: sustained in attentional blindness for dynamic events. Perception 28:1059-1074
94. Capra F (1996) The web of life: a new scientific understanding of living systems. Doubleday, New York

95. Sewall L (1995) The skill of ecological perception. In: Ecopsychology restoring the earth, healing the mind. Sierra Club Books, San Francisco

96. Schultz PW (2002) Inclusion with nature: the psychology of human-nature relations. In: Schmuck P, Schultz WP (eds) psychology of human-nature relations. Kluwer Academic, Norwell, pp 62-78

97. Raymond CM, Brown G, Weber D (2010) The measurement of place attachment: personal, community, and environmental connections. J Environ Psychol 30:422-434

98. Kals E, Schumacher D, Montada L (1999) Emotional affinity toward nature as a motivational basis to protect nature. Environ Behav 31:178-202

99. Cervinka R, Röderer K, Hefler E (2012) Are nature lovers happy? On various indicators of well-being and connectedness with nature. J Health Psychol 17:379-388

100. Tam K-P (2013) Dispositional empathy with nature. J Environ Psychol 35:92-104

101. Cheng JC-H, Monroe MC (2010) Connection to nature: children's affective attitude toward nature. Environ Behav 44:31-49

102. Bragg R, Wood C, Barton J, Pretty J (2013) Measuring connection to nature in children: a robust methodology for the RSPB. Colchester, pp 1-64. http://www.rspb.org.uk/Images/ methodology-report_tcm9-354606.pdf. Accessed 3 Feb 2014

103. Young J (2011) Personal communication. Art of Mentoring Workshop, Santa Cruz

104. Bragg E (1996) Towards ecological self: deep ecology meets constructionist self- theory. J Environ Psychol 16:93-108

105. Clayton S (2003) The environmental identity scale. In: Clayton S, Opotow S (eds) Identity and the natural environment: thepsychological significance of nature. MIT Press, Cambridge, pp 45-66

106. Naess A (2008) The ecology of wisdom: Writings by Arne Naess. In: Drengson A, Devall B (eds). Counterpoint, Berkeley

107. Howell AJ, Dopko RL, Passmore H-A, Buro K (2011) Nature connectedness: associations with well-being and mindfulness. Pers Individ Differ 51:166-171

108. Lin BB, Fuller Ra, Bush R et al (2014) Opportunity or orientation? Who uses urban parks and why. PLoS One 9:e87422

109. Allen J, Ferrand J (1999) Environmental locus of control, sympathy, and pro-environmental behavior. Environ Behav $31: 338-353$

110. Geller E (1995) Actively caring for the environment: an integration of behaviorism and humanism. Environ Behav 27:184-195

111. Maller C, Townsend M, Pryor A et al (2006) Healthy nature healthy people: "contact with nature" as an upstream health promotion intervention for populations. Health Promot Int 21:45-54

112. Dustin DL, Bricker KS, Schwab KA (2010) People and nature: toward an ecological model of health promotion. Leis Sci 32:3-14

113. Zelenski JM, Nisbet EK (2012) Happiness and feeling connected: the distinct role of nature relatedness. Environ Behav $\mathrm{XX}: 1-21$

114. Ballantyne R, Packer J, Sutherland LA (2011) Visitors' memories of wildlife tourism: implications for the design of powerful interpretive experiences. Tour Manag 32:770-779

115. Zylstra MJ (2014) Exploring meaningful nature experience, connectedness with nature and the revitalization of transformative education for sustainability. Department of Conservation Ecology \& Entomology, Stellenbosch University, Stellenbosch

116. Smith LDG (2007) A qualitative analysis of profound wildlife encounters. J Diss 1:184 
117. Morse M (2013) A quality of interrelating: describing a form of meaningful experience on a wilderness river journey. J Adventure Educ Outdoor Learn. doi:10.1080/14729679.2013.769713

118. Norton BG (1987) Why preserve natural variety? Princeton University Press, Princeton

119. Frederickson LM, Anderson DH (1999) A qualitiative exploration of the wilderness experience as a source of spiritual inspiration. J Environ Psychol 19:21-39

120. Ashley P (2007) Toward an understanding and definition of wilderness spirituality. Aust Geogr 38:53-69

121. Snell TL, Simmonds JG (2012) "Being in that environment can be very therapeutic" ": spiritual experiences in nature. Ecopsychology 4:326-335

122. De Pater C, Scherer-Rath M, Mertens F (2008) Forest managers' spiritual concerns. J Empir Theol 21:109-132

123. Beringer A (2003) A conservation psychology with heart. Hum Ecol Rev 10:150-153

124. Schroeder HW (1991) The spiritual aspect of nature: a perspective from depth psychology. In: Proceedings of northeastern recreation research conference. Saratoga Springs, NY. Retrieved 14 Nov 2013 from http://www.nrs.fs.fed.us/pubs/gtr/gtr_ne160/ gtr_ne160_025.pdf

125. Kellert SR, Farnham TJ (2002) Preface. In: Kellert SR, Farnham TJ (eds) Good in nature and humanity: connecting science, religion, and spirit with Nat. World. Island Press, Washington DC, pp xiii-xiv

126. Scharmer CO (2009) Theory U: leading from the future as it emerges. Berrett-Koehler Publishers, San Francisco

127. Young J (2013) New Year's message 2013: what is deep nature connection. In: 8 Shields Institute. http://jonyoung.org/2013/ 01/new-years-message-2013-what-is-deep-nature-connection/. Accessed 22 Jan 2013

128. Nisbet EK Nature relatedness research (nd) In: Carlet. University. http://cuhl.carleton.ca/Nisbet//E_Nisbet_Website-CU/Nat ure_Relatedness.html. Accessed 24 Jan 2013

129. Bruni CM, Chance R, Schultz PW, Nolan JM (2012) Natural connections: bees sting and snakes bite, but they are still nature. Environ Behav 44:197-215

130. Perrin JL, Benassi VA (2009) The connectedness to nature scale : a measure of emotional connection to nature ? J Environ Psychol 29:434-440

131. Hines JM, Hungerford HR, Tomera AN (1987) Analysis and synthesis of research on responsible environmental behavior: a meta-analysis. J Environ Educ 18:1-8

132. Fishbein M, Ajzen I (2010) Predicting and changing behaviour: the reasoned action approach. Psychology Press, New York

133. Guiney MS, Oberhauser KS (2009) Conservation volunteers' connection to nature. Ecopsychology 1:187-197

134. Schultz PW (2001) Assessing the structure of environmental concern: concern for self, other people, and the biosphere. J Environ Psychol 21:1-13

135. Roszak T (1995) Where psyche meets Gaia. In: Ecopsychology: restoring the earth healing the mind. Sierra Club Books, San Francisco

136. Mayer FS, Frantz CM, Bruehlman-Senecal E, Dolliver K (2009) Why is nature beneficial? The role of connectedness to nature. Environ Behav 41:607-643

137. Nisbet EK, Zelenski JM, Murphy SA (2011) Happiness is in our nature: exploring nature relatedness as a contributor to subjective well-being. J Happiness Stud 12:303-322

138. Ashmore RD, Deaux K, McLaughlin-Volpe T (2004) An organizing framework for collective identity: articulation and significance of multidimensionality. Psychol Bull 130:80-114

139. Ernst J, Theimer S (2011) Evaluating the effects of environmental education programming on connectedness to nature. Environ Educ Res 17:577-598
140. Stone AA, Turkkan JS, Bachrach CA et al (2000) The science of self-report: implications for research and practice. Lawrence Erlbaum, Mahwah

141. Hartig T, Kaiser FG, Bowler PA (2001) Psychological restoration in nature as a positive motivation for ecological behavior. Environ Behav Behav 33:590-607

142. Frantz C, Mayer F, Norton C, Rock M (2005) There is no "I" in nature: the influence of self-awareness on connectedness to nature. J Environ Psychol 25:427-436

143. Bruni CM, Schultz PW (2010) Implicit beliefs about self and nature: evidence from an IAT game. J Environ Psychol 30:95-102

144. Gosling E, Williams KJH (2010) Connectedness to nature, place attachment and conservation behaviour: testing connectedness theory among farmers. J Environ Psychol 30:298-304

145. Schultz PW, Zelezny LC (1998) Values and proenvironmental behavior: a five-country survey. J Cross Cult Psychol 29:540-558

146. Schultz PW, Zelezny LC (1999) Values as predictors of environmental attitudes: evidence for consistency across cultures. J Environ Psychol 19:255-265

147. Gough A (1999) Kids don't like wearing the same jeans as their mums and dads: so whose "life" should be in significant life experiences research? Environ Educ Res 5:383-394

148. Abram D (1996) The spell of the sensuous: perception and language in a more-than-human world. Pantheon Books, New York

149. Maffi L (2001) Introduction: on the interdependence of biological and cultural diversity. In: Biocultural diversity: linking language, knowledge and the environment. Smithsonian Institution Press, Washington, DC

150. Johnson RB, Onwuegbuzie AJ (2004) Mixed methods research: a research paradigm whose time has come. Educ Res 33:14-26

151. Maiteny P (2004) Perceptions of nature by Indigenous communities. In: Burley J, Evans J, Youngquist J (eds) Encyclopedia of forest science. Elsevier, Oxford, pp 462-471

152. Chawla L (2006) Research methods to investigate significant life experiences: review and recommendations. Environ Educ Res 12:359-374

153. DeMares R, Krycka K (1998) Wild-animal triggered peak experiences: transpersonal aspects. J Transpers Psychol 30:161-177

154. Smith LDG, Ham SH, Weiler BV (2011) The impacts of profound wildlife experiences. Anthrozoos 24:51-64

155. Tanner T (1980) Significant life experiences: a new research area in environmental education. J Environ Educ 11:20-24

156. Chawla L (1998) Significant life experiences revisited. J Environ Educ 29:11-21

157. Bögeholz S (2006) Nature experience and its importance for environmental knowledge, values and action: recent German empirical contributions. Environ Educ Res 12:65-84

158. White MP, Pahl S, Ashbullby K et al (2013) Feelings of restoration from recent nature visits. $\mathrm{J}$ Environ Psychol $35: 40-51$

159. Hinds J, Sparks P (2008) Engaging with the natural environment: the role of affective connection and identity. J Environ Psychol 28:109-120

160. Rogers Z, Bragg E (2012) Thinable lifestyles and sense of place. Ecopsychology 4:307-318

161. Raymond CM, Brown G, Robinson GM (2011) The influence of place attachment, and moral and normative concerns on the conservation of native vegetation : a test of two behavioural models. J Environ Psychol 31:323-335

162. Russell KC, Hendee JC, Phillips-Milller D (1999) Wilderness therapy works: an examination of the wilderness therapy process to treat adolescents with behavioural problems and addictions. 
In: Wilderness science in a time of change conference, vol 3, pp 207-217

163. De Wet B (2007) Influence of wilderness experience on the adoption of environmentally responsible behaviour. Sustainable Development Planning and Management, University of Stellenbosch, Stellenbosch

164. Kaplan S, Talbot J (1983) Psychological benefits of a wilderness experience. In: Altman I, Wohlwill JF (eds) Behavior and the natural environment. Plenum, New York, pp 214-230

165. Bragg E, Reser J (2012) Ecopsychology in the antipodes: perspectives from Australia and New Zealand. Ecopsychology $4: 253-354$

166. Shaw S (2003) Connecting to nature's spirit. Gatherings August. http://www.ecopsychology.org/journal/gatherings $8 / \mathrm{h}$

167. Cohen MJ (1993) Well mind, well earth: 97 environmentally sensitive activities for stress management, spirit and self-esteem. In: Continuing education training manual: environmental education ethics and counseling psychology. World Peace University, Eugene. http://eric.ed.gov/?id=ED364805. Accessed 15 Sept 2014

168. White PR (2012) Enhancing the experience of connection with nature: participants' responses to the MAPIN strategy. Ecopsychology 4:345-353

169. Cook E (2013) 5:2 your life: the screen diet. In: The guardian. http://www.guardian.co.uk/lifeandstyle/2013/jun/14/5-2-your-lifescreen-diet?CMP=ema_632. Accessed 17 June 2013

170. Young J, Morgan T (2007) Animal tracking basics. Stackpole Books, Mechanicsburg

171. Hine R (2008) Care farming: bringing together agriculture and health. ECOS 29:42-51

172. Natural-England (2012) Natural England's submission to the National Trust's Natural Childhood Inquiry. http://www.natur alengland.org.uk/images/12-13-003_natural\%20childhood\%20 inquiry_tcm6-32639.pdf. Accessed 8 Feb 2014

173. Higgins $P$ (1996) Outdoor education for sustainability: making connections. J Adventure Educ Outdoor Leadersh 13:4-11

174. Williams A (2012) Taking a step back: learning without the facilitator on solo activities. Adventure Educ Outdoor Learn 12:137-155

175. Teisl MF, Brien KO (2003) Who cares and who acts?: outdoor recreationists exhibit different levels of environmental concern and behavior. Environ Behav 35:506-522

176. Harper NJ, Carpenter C, Segal D (2012) Self and place. Journeys Land 4:319-325

177. Blythe C, Harré N (2012) Inspiring youth sustainability leadership: six elements of a transformative youth eco-retreat. Ecopsychology 4:336-344

178. Feral C-H (1998) The connectedness model and optimal development: is ecopsychology the answer to emotional wellbeing? Humanist Psychol 26:243-274

179. Gardner H (1999) Intelligence reframed: multiple intelligences for the 21st century. Basic Books, New York

180. Hayes MA (2009) Into the field: naturalistic education and the future of conservation. Conserv Biol 23:1075-1079

181. Bortroft H (1996) The wholeness of nature: Goethe's way of science. Floris Books, Edinburgh

182. Ulrich R (1993) Biophilia, biophobia and natural landscapes. In: Kellert SR, Wilson EO (eds) The biophilia hypothesis. Island Press, Washington, DC, pp 73-137

183. Lemelin RH (2013) To bee or not to bee: Whether 'tis nobler to revere or to revile those six-legged creatures during one's leisure. Leisure Stud 32:153-171. doi:10.1080/02614367.2011. 626064

184. Elgin D (1993) Voluntary simplicity: toward a way of life that is outwardly simple, inwardly rich, Revised. William Morrow and Company, Inc., New York
185. Fishbein M, Manfredo M (1992) A theory of behavior change. In: Influencing human behavior: theory and applications in recreation, tourism, and natural resources management. Sagamore Publishing, Champaign

186. Brymer E, Cuddihy T, Sharma-Brymer V (2010) The role of nature-based experiences in the development and maintenance of wellness. Asia-Pacific J Heal Sport Phys Educ 1:21-27

187. Atchley RA, Strayer DL, Atchley P (2012) Creativity in the wild: improving creative reasoning through immersion in natural settings. PLoS One 7:e51474

188. Faber Taylor A, Kuo FE, Sullivan WC (2001) Coping with ADD: the surprising connection to green play settings. Environ Behav 33:54-77

189. Kuo FE, Faber Taylor A (2004) A potential natural treatment for attention-deficit/hyperactivity disorder: evidence from a national study. Am J Public Health 94:1580-1586

190. Faber Taylor A, Wiley A, Kuo FE, Sullivan WC (1998) Growing up in the inner city: green spaces as places to grow. Environ Behav 30:3-27

191. Faber Taylor A, Kuo FE, Sullivan WC (2002) View of nature and self-discipline: evidence from inner city children. J Environ Psychol 22:49-63

192. Maslow AH (1964) Religion, values and peak-experiences. Ohio State University Press, Columbus

193. Rolston III H (1994) Conserving natural value. Columbia University Press, New York

194. Hoot RE, Friedman H (2011) Connectedness and environmental behavior: sense of interconnectedness and pro-environmental behavior. Int J Transpers Stud 30:89-100

195. Fazio RH, Zanna P (1981) Direct experience and attitudebehaviour consistency. Adv Exp Soc Psychol 14:161-202

196. Manzo LC (2003) Beyond house and haven: toward a revisioning of emotional relationships with place. J Environ Psychol 23:47-61

197. Maiteny P (2002) Mind in the gap: summary of research exploring "inner" influences on pro-sustainability learning and behaviour. Environ Educ Res 8:299-306

198. Lockwood J (2013) The philosophical and psychological dimensions of insects: Tourism, horror and the negative sublime. In: Lemelin RH (ed) Management of insects in recreation and tourism. Cambridge University Press, New York, pp 37-55

199. Hull RB (2014) Valuing urban forest: lessons to learn from hurricanes. In: Tidball KG, Krasny ME (eds) Greening in the red zone: disaster, resilience and community green. Springer, Dordrecht, pp 249-255

200. Thomashow M (1995) Ecological identity: becoming a reflective environmentalist. MIT Press, Cambridge

201. Chawla L (2014) Children's engagement with the natural world as a ground for healing. In: Krasny ME, Tidball KG (eds) Greening in the red zone: disaster, resilience and community green. Springer, Dordrecht, pp 111-124

202. Chawla L (1990) Ecstatic places. Child Environ Q 7:18-23

203. Hinton R (2000) Seen but not heard: refugee children and models for intervention. In: Abandoned children. Cambridge University, Cambridge

204. Boyden J, Mann G (2005) Children's risk, resilience and coping in extreme situations. In: Boyden J, Mann G (eds) The handbook for working with children \& youth: pathways to resilience across cultures and contexts. pp 3-26

205. Chatterjee S (2007) Children's role in humanizing forced evictions and resettlements in Delhi. Child Youth Environ 17:198-221

206. Whitten T, Holmes D, MacKinnon K (2001) Conservation biology: a displacement behavior for academia? Conserv Biol $12: 1-3$ 
207. Biotropica (2009) Sharing ecological knowledge: conquering the research-implementation gap (special section). Biotropica 41:531-588

208. Yamauchi T (2001) Wang Yang-Ming. In: Palmer JA (ed) Fifty key thinkers environ. Routledge, New York, pp 27-33

209. Durant W (1926) The story of philosophy: the lives and opinions of the greater philosophers. Simon \& Schuster, New York

210. Fazey I, Fischer J, Lindenmayer B (2005) What do conservation biologists publish? Biol Conserv 124:63-73

211. Mascia MB, Brosius JP, Dobson TA et al (2003) Conservation and the social sciences. Conserv Biol 17:649-650

212. Cowling RM (2005) Maintaining the research-implementation continuum in conservation. Soc Conserv Biol Newsl 12(1):19

213. Muir MJ, Schwartz MJ (2009) Academic research training for a nonacademic workplace: a case study of graduate student alumni who work in conservation. Conserv Biol 23:1357-1368

214. Swan JA (2010) Transpersonal psychology and the ecological conscience. J Transpers Psychol 42:2-25

215. Tanner C (2003) Steps to transdisciplinary sustainability research. Hum Ecol Rev 10:180-182

216. Max-Neef MA (2005) Foundations of transdisciplinarity. Ecol Econ 53:5-16

217. Jahn T (2008) Transdisciplinarity in the practice of research. In: Bergmann M, Schramm E (eds) Transdisziplinäre forschung, integrative forschungsprozesse verstehen und bewerten, Integrative forschungsprozesse verstehen und bewerten. Campus Verlag, Frankfurt, pp 21-37

218. Esbjörn-Hargens S, Zimmerman ME (2009) Integral ecology: uniting multiple perspectives on the natural world. Integral Books (Shambhala Publications), Boston

219. Redford KH, Sanjayan MA (2003) Retiring Cassandra. Conserv Biol 17:1473-1474

220. Kaplan S (2000) Human nature and environmentally responsible behaviour. J Soc Issues 56:491-508

221. Gruenewald DA (2003) The best of both worlds: a critical pedagogy of place. Educ Res 32:3-12

222. Shellenberger M, Nordhaus $T$ (2004) The death of environmentalism to the politics of possibility. Houghton Mifflin, Boston

223. Linden M (2003) Posttraumatic embitterment disorder. Psychother Psychosom 72:195-202

224. Swan JA (2011) Personal communication. (Email correspondence)

225. Kübler-Ross E (1969) On death and dying. Routledge, London

226. Hobbs R (2011) Conservation in production landscapes: can we have our cake and eat it too? International Congress for Conservation Biology, 5-9 December 2011, Auckland

227. Lidicker WZ (2011) Hope and realism in conservation biology. Bioscience 61:94

228. Harré N (2011) Psychology for a better world: strategies to inspire sustainability. University of Auckland, Auckland

229. Wals AEJ, Geerling-eijff F, Hubeek F et al (2008) All mixed up? Instrumental and emancipatory learning toward a more sustainable world: considerations for EE policymakers. Environ Educ 7:55-65

230. Shallcross A (1996) Caring for the environment: can we be effective without the affective? Environ Educ Inf 15:121-134

231. Redford KH, Padoch C, Sunderland T (2013) Fads, funding, and forgetting in three decades of conservation. Conserv Biol 27:437-438

232. Rudd MA (2011) Scientists' opinions on the global status and management of biological diversity. Conserv Biol 25: $1165-1175$

233. Brosius JP (2006) Common ground between anthropology and conservation biology. Conserv Biol 20:683-685

234. Sommer R (2003) Action research and big fuzzy concepts. Hum Ecol Rev 10:176-177
235. Sommer R, Sommer B (2002) A practical guide to behavioral research, 5th edn. Oxford University Press, New York

236. Knight AT, Cowling RM (2007) Embracing opportunism in the selection of priority conservation areas. Conserv Biol 21:1124-1126

237. WWF (2005) Beyond belief: Linking faiths and protected areas to support biodiversity conservation. WWF, Gland

238. Cocks M, Dold T, Vetter S (2012) God is my forest: Xhosa cultural values provide untapped opportunities for conservation. S Afr J Sci 108:Art\# 880

239. Verschuuren B, Wild R, McNeely JA, Oviedo G (2010) Sacred natural sites: conserving nature \& culture. Routledge, London

240. Maffi L (2005) Linguistic, cultural, and biological diversity. Annu Rev Anthropol 34:599-617

241. Suzuki D (1999) Finding a new story. Cultural and spiritual values of biodiversity, a complementary contribution to the UNEP global biodiversity assessment

242. Schulze S (2005) Paradigms, ethics and religion in environmental education. In: Loubser C (ed) Environmental education: some South African perspectives. Van Schaik Publishers, Pretoria, pp 57-71

243. Shaw S, Cock P, Bates M, Jeffrey S (2003) The Australia issue. Gatherings. J Int Community Ecopsychology. http://www.ecop sychology.org/journal/gatherings $8 / \mathrm{html}$. Accessed 18 June 2013

244. Chawla L (1994) In the first country of places: nature, poetry, and childhood memory. University of New York, New York

245. Darwin C (1859) On the origin of species by means of natural selection, or, the preservation of favoured races in the struggle for life. John Murray, London

246. Wilson EO (1984) Biophilia. Harvard University Press, Cambridge

247. Simaika JP, Samways MJ (2010) Biophilia as a universal ethic for conserving biodiversity. Conserv Biol 24:903-906

248. Hull DL (2002) Nurturing a view of human nature. Nature 419:251-252

249. Verbeek P, de Waal FBM (2002) The primate relationship with nature: biophilia as a general pattern. In: Kahn PH, Kellert SR (eds) Children and nature: psychological, sociocultural, and evolutionary investigations. MIT Press, Cambridge, pp 1-28

250. Baumeister RF, Leary MR (1995) The need to belong: desire for interpersonal attachments as a fundamental human motivation. Psychol Bull 117:497-529

251. Cacioppo JT, Patrick W (2008) Loneliness: human nature and the need for social connection. WW Norton \& Company, New York

252. Aitkenhead D (2010) How the internet has brought out our creativity - and generosity. In: Sydney Morning Her. http:// www.smh.com.au/technology/technology-news/nice-and-nastydoes-it-shirky-the-net-guru-on-what-the-future-holds-20100705zww5.html. Accessed 14 July 2010

253. Holling CS (2001) Understanding the complexity of economic, ecological, and social systems. Ecosystems 4:390-405

254. Salafsky N, Margoluis R, Redford KH, Robinson JG (2002) Improving the practice of conservation: a conceptual framework and research agenda for conservation science. Conserv Biol $16: 1469-1479$

255. Lopez B (2003) The language of animals. A place on earth: an anthology of nature writing from Australia and North America

256. Shava $S$ (2013) The representations of indigenous knowledges. In: Stevenson RB, Brody M, Dillon J, Wals AEJ (eds) International handbook of research on environmental education. Routledge, New York, pp 384-393

257. Guattari F (2001) The three ecologies. The Athlone Press, London

258. Le Grange L (2011) Ubuntu, ukama and the healing of nature, self and society. Educ Philos Theory 44:56-67

259. Hay PR (2002) Main currents in western environmental thought. University of New South Wales Press Ltd., Sydney 
260. Laszlo E (2010) Quantum consciousness: our evolution, our salvation. In: Huffingt. Post. http://www.huffingtonpost.com/ ervin-laszlo/quantum-consciousness-our_b_524054.html. Accessed 12 June 2012

261. Gruenewald DA (2005) Accountability and collaboration: institutional barriers and strategic pathways for place-based education. Ethics Place Environ 8:261-283

262. Davies K, Cohen MJ (1995) Reconnecting with nature: educational self-esteem sensory activities for reducing drug use and irresponsible relationships in students at risk. Reconnecting with National University of Global Education, Friday Harbor

263. Waterhouse $\mathbf{J}$ (2011) Finding balance between human need and global stewardship. Conserv Biol 25:1087-1090

264. Chawla L, Cushing DF (2007) Education for strategic environmental behavior. Environ Educ Res 13:437-452

265. Bohm D (1980) Wholeness and the implicate order. Routledge, London

266. Schultz PW, Zelezny LC, Dalrymple NJ (2000) A multinational perspective on the relation between Judeo-Christian religious beliefs and attitudes of environmental concern. Environ Behav 32:576-591

267. Gardner GT, Stern PC (2002) Environmental problems and human behavior, 2nd edn. Pearson Custom Publishing, Boston

268. McFague S (1997) Super, natural Christians. Fortress Press, Minneapolis

269. Kohák E (2003) An understanding heart: reason, value, and transcendental phenomenology. In: Brown CS, Toadvine T (eds) Eco-phenomenology back to earth itself. SUNY Press, New York, pp 19-36

270. Riley-Taylor E (2002) Ecology, spirituality \& education: curriculum for relational knowing. Peter Lang, New York

271. Brown CS, Toadvine T (2003) Eco-phenomenology: back to the earth itself. SUNY Press, New York

272. Shepard P (1973) The tender carnivore and the sacred game. Scribner's, New York

273. Shepard P (1982) Nature and madness. Sierra Club Books, San Francisco

274. Quinn D (1992) Ishmael. Bantam/Turner Books, New York

275. Cock J (2007) The war against ourselves: nature, power and justice. Wits University Press, Johannesburg

276. Cronon W (1991) Nature's metropolis. Norton, New York

277. Taylor S (2010) Waking from sleep: why awakening experiences occur and how to make them permanent. Hay House, London

278. Silberbauer GB (1981) Hunter and habitat in the Central Kalahari Desert. Cambridge University Press, Cambridge

279. Kimmerer RW (2002) Weaving traditional ecological knowledge into biological education: a call to action. Bioscience $52: 432-438$

280. Gifford R (1976) Environmental numbness in the classroom. J Exp Educ 44:4-7

281. Stilgoe JR (2001) Gone barefoot lately? Am J Prev Med 20:243-244
282. Kahn PHJ (2002) Children's affiliations with nature: structure, development, and the problem of environmental generational amnesia. In: Kahn PH, Kellert SR (eds) Children and nature: psychological, sociocultural, and evolutionary investigations. MIT Press, Cambridge, Massachusetts, pp 93-116

283. Pauly D (1995) Anecdotes and the shifting baseline syndrome of fisheries. Trends Ecol Evol 10:430

284. Kellert SR (2005) Building for life: designing and understanding the human-nature connection. Island Press, Washington

285. Maslow AH (1970) Motivation and personality. Harper \& Row Publishers, London

286. Myers Jnr O (1998) Children and animals. Westview, Boulder

287. Csikszentmihalyi M (2003) Creating a disciplinary transformation and forging a planetary psychology. Hum Ecol Rev 10:159-161

288. Samways M (2007) Rescuing the extinction of experience. Biodivers Conserv 16:1995-1997

289. Ehrlich PR (1968) The population bomb. Buccaneer Books, Cutchogue

290. Dunlap RE, Van Liere KD, Mertig AG, Jones RE (2000) Measuring endorsement of the new ecological paradigm: a revised NEP scale. J Soc Issues 56:425-442

291. Perkins HE (2010) Measuring love and care for nature. J Environ Psychol 30:455-463

292. Brügger A, Kaiser FG, Roczen N (2011) One for all? Eur Psychol 16:324-333

293. Macy JR, Young Brown M (1998) Coming back to life: practices to reconnect our lives, our world. New Society Publishers, Gabriola Island

294. Sveiby KE, Skuthorpe T (2006) Treading lightly: the hidden wisdom of the world's oldest people. Allen \& Unwin, Crows Nest

295. McKenzie-Mohr D (2000) Fostering sustainable behavior through community-based social marketing. Am Psychol 55:531-537

296. Harper D (2013) "Spirit." In: Online Etymology Dict. http:// www.etymonline.com/index.php?allowed_in_frame $=0 \&$ search $=$ spirit\&searchmode=none. Accessed 17 Oct 2013

297. Harper D (2013) “Inspiration.” In: Online Etymology Dict. http:// www.etymonline.com/index.php?allowed_in_frame $=0 \&$ search $=$ inspiration\&searchmode $=$ none. Accessed 18 Oct 2013

298. Nepstad DC, McGrath DG, Soares-Filho B (2011) Systemic conservation, REDD, and the future of the Amazon Basin. Conserv Biol 25:1113-1116

299. Hannah L (2011) Climate change, connectivity, and conservation success. Conserv Biol 25:1139-1142

300. Hellman JJ, Pfrender ME (2011) Future human intervention in ecosystems and the critical role for evolutionary biology. Conserv Biol 25:1143-1147

301. McCay BJ, Jones PJS (2011) Marine protected areas and the governance of marine ecosystems and fisheries. Conserv Biol 25:1130-1133 